\title{
Cycling and retention of nitrogen in European beech (Fagus sylvatica L.) ecosystems under elevated fructification frequency
}

\author{
Rainer Brumme ${ }^{1}$, Bernd Ahrends ${ }^{2}$, Joachim Block ${ }^{3, \text { 死, Christoph Schulz }}{ }^{4}$, Henning Meesenburg ${ }^{2}$, Uwe Klinck ${ }^{2}$, \\ Markus Wagner ${ }^{2}$, and Partap K. Khanna ${ }^{5, \varpi}$ \\ ${ }^{1}$ Soil Science of Tropical and Subtropical Ecosystems, Faculty of Forest Science and Forest Ecology, \\ Georg-August-Universität Göttingen, 37073 Göttingen, Germany \\ ${ }^{2}$ Department of Environmental Control, Northwest German Forest Research Institute (NW-FVA), Göttingen, Germany \\ ${ }^{3}$ Department for Forest Monitoring, Research Institute for Forest Ecology and Forestry Rhineland-Palatinate (FAWF), \\ Hauptstraße 16, 67705 Trippstadt, Germany \\ ${ }^{4}$ Department of Forest Policy, Counseling and Ownership, Bavarian State Institute of Forestry (LWF), Freising, Germany \\ ${ }^{5}$ Soil Science of Temperate and Boreal Ecosystems, Faculty of Forest Science and Forest Ecology, \\ Georg-August-Universität Göttingen, 37073 Göttingen, Germany \\ $i$ retired
}

Correspondence: Bernd Ahrends (bernd.ahrends@nw-fva.de)

Received: 18 January 2021 - Discussion started: 20 January 2021

Revised: 18 May 2021 - Accepted: 27 May 2021 - Published: 23 June 2021

\begin{abstract}
Atmospheric deposition of nitrogen (N) has exceeded its demand for plant increment in forest ecosystems in Germany. High $\mathrm{N}$ inputs increased plant growth, the internal $\mathrm{N}$ cycling within the ecosystem, the retention of $\mathrm{N}$ in soil and plant compartments, and the $\mathrm{N}$ output by seepage water. But the processes involved are not fully understood, notably the effect of fructification in European beech (Fagus sylvatica L.) on $\mathrm{N}$ fluxes. The frequency of fructification has increased together with air temperature and $\mathrm{N}$ deposition, but its impact on $\mathrm{N}$ fluxes and the sequestration of carbon (C) and $\mathrm{N}$ in soils have been hardly studied. A field experiment using ${ }^{15} \mathrm{~N}$-labeled leaf litter exchange was carried out over a 5.5-year period at seven long-term European beech (Fagus sylvatica L.) monitoring sites to study the impact of current mast frequency on $\mathrm{N}$ cycling. Mean annual leaf litterfall contained $35 \mathrm{~kg} \mathrm{~N} \mathrm{ha}^{-1}$, but about one-half of that was recovered in the soil 5.5 years after the establishment of the leaf litter ${ }^{15} \mathrm{~N}$ exchange experiment. In these forests, fructification occurred commonly at intervals of 5 to 10 years, which has now changed to every 2 years as observed during this study period. Seed cupules contributed $51 \%$ to the additional litterfall in mast years, which creates a high nutrient demand during their decomposition due to the very high ratios of $\mathrm{C}$ to $\mathrm{N}$ and $\mathrm{C}$ to phosphorus (P). Retention of leaf litter ${ }^{15} \mathrm{~N}$ in the soil
\end{abstract}

was more closely related to the production of total litterfall than to the leaf litterfall, indicating the role of seed cupules in the amount of leaf $\mathrm{N}$ retained in the soil. Higher mast frequency increased the mass of mean annual litterfall by about $0.5 \mathrm{Mg} \mathrm{ha}^{-1}$ and of litterfall $\mathrm{N}$ by $8.7 \mathrm{~kg} \mathrm{ha}^{-1}$. Mean net primary production (NPP) increased by about $4 \%$. Mean total $\mathrm{N}$ retention in soils calculated by input and output fluxes was unrelated to total litterfall, indicating that mast events were not the primary factor controlling total $\mathrm{N}$ retention in soils. Despite reduced $\mathrm{N}$ deposition since the 1990s, about 5.7 out of $20.7 \mathrm{~kg} \mathrm{~N} \mathrm{ha}^{-1}$ deposited annually between 1994 and 2008 was retained in soils, notably at acid sites with high $\mathrm{N} / \mathrm{P}$ and $\mathrm{C} / \mathrm{P}$ ratios in the organic layers and mineral soils, indicating $\mathrm{P}$ limitation for litter decomposition. Trees retained twice as much $\mathrm{N}$ compared to soils by biomass increment, particularly in less acidic stands where the mineral soils had low $\mathrm{C} / \mathrm{N}$ ratios. These results have major implications for our understanding of the $\mathrm{C}$ and $\mathrm{N}$ cycling and $\mathrm{N}$ retention in forest ecosystems. In particular the role of mast products in $\mathrm{N}$ retention needs more research in the future. 


\section{Introduction}

Nitrogen $(\mathrm{N})$ was commonly a limiting nutrient in the pristine temperate forests. However, several decades of elevated atmospheric deposition of $\mathrm{N}$ and acidity changed biogeochemical $\mathrm{N}$ cycles in temperate forest ecosystems in large regions of the Northern Hemisphere. Atmospheric depositions decreased soil pH (Hallbäcken and Tamm, 1986) and affected the $\mathrm{N}$ cycling through reduced decomposition across a wide range of forest ecosystems (Persson and Wirén, 1993; Janssens et al., 2010). Carbon (C) / $\mathrm{N}$ ratios in the organic layers were reduced, and $\mathrm{C}$ sequestration in forest soils increased (De Vries et al., 2006; Hyvönen et al., 2008; Meiwes et al., 2009). High atmospheric deposition of N removed $\mathrm{N}$ deficiency in forest ecosystems (LeBauer and Treseder, 2008), increased foliar $\mathrm{N}$ contents, and reduced the contents of foliar phosphorus (P) (Braun et al., 2010; Talkner et al., 2015). Probably in combination with high inputs of base cations (Meesenburg et al., 2009), N deposition accelerated forest growth to a certain degree (De Vries et al., 2014; Etzold et al., 2020). In contrast to reduced sulfur emission since the beginning of the 1980s (Engardt et al., 2017), N deposition still exceeds the $\mathrm{N}$ demand for forest growth in unmanaged and most managed forests (Meesenburg et al., 2016; Fleck et al., 2019).

Leaf litterfall plays a key role in the internal $\mathrm{N}$ cycle of temperate beech forests by adding a large amount of rapidly mineralizable $\mathrm{N}$ annually to the soil (Meier et al., 2005; Neumann et al., 2018). However, the amount of $\mathrm{N}$ transferred to the soil with total litterfall is regulated to a large extent by the amount and frequency of fructification (Khanna et al., 2009). There is increasing evidence that the frequency of fructification in beech forests has increased when compared to that in the past decades: it was well known from the older literature that the fruiting of beech trees was periodic, and heavy fructification happened once every 5 to 10 years in the past. For example, Hase (1964) calculated the return of a full-mast every 10 years and of a half- and full-mast every 5 years over 240 years of mast protocols (1721-1960) in SchleswigHolstein, Germany. Mast protocols were used to calculate the number of hogs allowed to drive into the forests, which was economically important until the 1930s. Övergaard et al. (2007) calculated, by using literature data from the end of the 17th century up to the 1960 s, that mast frequency in Sweden was every 4 to 6 years. A review by Wachter (1964), and extended by Paar et al. (2011), summarized the observations of mast events between 1839 and 1987 in Germany and calculated a recurrence interval of heavy fructification (full-mast and half-mast) of 4.7 years. When comparing older studies, it should be mentioned that the definition of a mast year was not based on uniform protocols in the past.

The classification of fructification in full-mast, half-mast, "spreng"-mast (sprinkle amount), and missing mast is based on litter trap measurements during the last 3 decades which allowed a better quantification of mast events. According to the classification given by Burschel (1966), which is based on the numbers of seeds in litterfall, a full-mast has more than 150 seeds per square meter, half-mast $100-150$ seeds, and spreng-mast 50-100 seeds. Based on this protocol, Paar et al. (2011) calculated that full-masts occurred every 2.6 years during 1988 and 2010 in 10 monitoring plots in Hesse and Lower Saxony, Germany. A similar mast interval was reported for 1981 to 2004 by Schmidt (2006) and Khanna et al. (2009) and for 2000 to 2012 by Reil et al. (2015) for beech sites in Germany. For southern Sweden, a mast interval of 2.5 years was reported by Övergaard et al. (2007) for the period between 1974 and 2006, which was based on a threshold value of 50 seeds per square meter for a mast year. A fruit-bearing cycle with a 2-year return period appeared in 20 European beech stands from 1994 to 2007 in France, which was based on collecting leaves and nuts in litter traps (Lebourgeois et al., 2018).

Differences in summer temperature between the 2 years preceding mast may affect the fruit production (Kelly et al., 2013; Vacchiano et al., 2017; Lebourgeois et al., 2018; Nussbaumer et al., 2018). Mund et al. (2020) reported that a positive effect of summer precipitation 2 years prior to fruit production was observed at a beech forest in Thuringia, Germany. A requirement for mast production is the availability of $\mathrm{N}$ because nuts are rich in $\mathrm{N}$ (Bogdziewicz et al., 2017). The demand for $\mathrm{N}$ in the mast years was double that of nonmast years in beech forests in Germany (Khanna et al., 2009). High $\mathrm{N}$ concentrations in leaves of beech trees are not related to the soil fertility in different parent materials (Meier et al., 2005), and the frequent fructification in large areas of Europe (Nussbaumer et al., 2016) point to a high $\mathrm{N}$ availability in these forests after several decades of high $\mathrm{N}$ deposition (Galloway et al., 2008). Several studies focused on the role of litter quality on $\mathrm{N}$ fluxes and $\mathrm{N}$ retention in forest ecosystems (e.g. Berg and McClaugherty, 2020). The extent to which a higher mast frequency changes soil biota, decomposition processes, $\mathrm{N}$ fluxes, and $\mathrm{N}$ retention in forest soils has been hardly studied.

The objective of our study was to determine the influence of a high frequency of fructification on $\mathrm{N}$ fluxes in European beech ecosystems (Fagus sylvatica $\mathrm{L}$.). To achieve this objective, we used seven European beech stands of Level II sites in Germany, where a number of input-output $\mathrm{N}$ fluxes and internal $\mathrm{N}$ fluxes were monitored for 15 years to assess the effect of mast production on $\mathrm{N}$ fluxes. In addition to the regular monitoring program, we carried out a ${ }^{15} \mathrm{~N}$-labeled leaf litter exchange experiment at these sites to study the retention of leaf litter $\mathrm{N}$ in the soil under the different frequencies of fructification and site conditions. 


\section{Material and methods}

\subsection{Study sites}

Seven long-term monitoring sites with European beech ( $\mathrm{Fa}$ gus sylvatica L.) as the dominant deciduous tree species in Germany were selected for the study. The study sites are Level II plots of the ICP Forests Intensive Monitoring Programme established under the UNECE Convention on LongRange Transboundary Air Pollution (De Vries et al., 2003a). The Level II Intensive Forest Monitoring is carried out at about 800 selected forest ecosystems representative of the major European forest types with the aim to study the relationships between stress factors such as air pollution and forest ecosystem responses. The Level I monitoring is based on a systematic $16 \times 16 \mathrm{~km}$ grid and covers around 6000 plots, where annual crown condition assessments are carried out. So far, two forest soil condition surveys were conducted from 1985 to 1996 and 2004 to 2008, respectively (Cools and de Vos, 2011).

Three of our sites are located in Bavaria at Bad Brückenau (BBR, Level II plot 903), Freising (FRE, 919), and Ebrach (EBR, 907); two sites in Lower Saxony at Solling (SOB, 304) and Göttinger Wald (GW, 306); one site in Hesse at Homberg (HOM, 607); and three sites in Rhineland-Palatinate, one at Neuhäusel (NHB, 704) and two other sites (Kirchheimbolanden, KHB, and Neuhäusel Quarz, NHQ). KHB and NHQ were evaluated with respect to the litterfall fractions in order to disentangle the different properties of seeds and seed cupules (Table 4). The plots are located at 375 to $850 \mathrm{~m}$ above sea level (Table 1). The slope of the sites ranges from almost flat to a maximum inclination of $7.4^{\circ}$. Mean temperature ranged from 6.0 to $8.3^{\circ} \mathrm{C}$ and mean annual precipitation from 712 to $1209 \mathrm{~mm}$. Soil $\mathrm{pH}\left(\mathrm{H}_{2} \mathrm{O}\right)$ in $0-10 \mathrm{~cm}$ depth ranged from 3.6 to 6.1. The organic layers on these sites varied from mull-type humus with $4 \mathrm{MgC} \mathrm{ha}^{-1}$ to modertype humus with $34 \mathrm{MgC} \mathrm{ha}^{-1}$ (Table 2). Clay content in 0 $10 \mathrm{~cm}$ soil depth ranged from $12 \%-40 \%$ and sand content from 3\%-39\%. Detailed information on soil properties can be obtained in Fleck et al. (2016). All forest sites are stocked with mature beech stands with mean ages of 94 to 163 years (2010) and stand densities of 140 to 452 trees per hectare.

\subsection{Methods}

\subsubsection{Measurements and calculations of $\mathrm{N}$ fluxes}

Changes of the soil $\mathrm{N}$ pools $\left(\Delta \mathrm{N}_{\mathrm{S}}\right)$ were calculated for managed forests with a closed $\mathrm{N}$ cycling between plants and soil by input and output fluxes as follows (all values given in $\left.\mathrm{kg} \mathrm{ha}^{-1} \mathrm{yr}^{-1}\right)$ :

$\Delta \mathrm{N}_{\mathrm{S}}=N_{\mathrm{D}}+N_{\mathrm{F}}-N_{\mathrm{L}}-N_{\mathrm{E}}-N_{\mathrm{U}}$,

where $N_{\mathrm{D}}$ is the total $\mathrm{N}$ deposition from the atmosphere, $N_{\mathrm{F}}$ the $\mathrm{N}$ input by biological fixation, $N_{\mathrm{L}}$ the seepage output of
$\mathrm{N}$ below the root zone, $N_{\mathrm{E}}$ the net gaseous $\mathrm{N}$ exchange, and $N_{\mathrm{U}}$ the net $\mathrm{N}$ uptake for tree increment.

We are aware that there is a high degree of uncertainty associated with the estimates of $\mathrm{N}$ inputs and outputs for the $\mathrm{N}$ balance (e.g. Ahrends et al., 2020; De Vries et al., 2003b). However the $\mathrm{N}$ balance is a useful tool for determining small changes in soil $\mathrm{N}$ pools and is much more sensitive than the repeated soil inventories (De Vries et al., 2006; Brumme and Khanna, 2008; Fleck et al., 2019).

The terms in Eq. (1) were quantified as follows for the period from 1994 to 2008.

Total $\mathrm{N}$ deposition $\left(N_{\mathrm{D}}\right)$ was calculated from open-field deposition, throughfall deposition, and stemflow inputs by using a canopy budget model as described by Ulrich (1994). Sampling design was very similar for all sites. Precipitation was sampled with funnel-flask samplers; three to six samplers were used for open field and 15 for throughfall deposition (Clarke et al., 2016). At the Bavarian sites throughfall samplers were reduced to five samplers in wintertime. Stemflow was sampled by fixing polyurethane spirals around the stems, which were coated with paraffin. At each site 3 to 10 trees were selected for stemflow measurement. Seepage N output $\left(N_{\mathrm{L}}\right)$ was estimated by multiplication of soil solution concentration and seepage water flux, which was obtained by using a hydrological model. Soil solution was collected with suction cups (tension lysimeters, two to nine collectors at each site) at 90 or $100 \mathrm{~cm}$ depth of the mineral soil (Nieminen et al., 2016). At the BBR site, lysimeters were installed at $60 \mathrm{~cm}$ soil depth due to the shallow nature of the soil, and at the EBR and FRE sites they were installed at 120 and $140 \mathrm{~cm}$ depths, respectively. Soil solution and precipitation samples were collected weekly or fortnightly (at Bavarian sites a 3week interval was used) and were pooled to monthly samples for chemical analysis. Analytical methods as described by König et al. (2009) and the UNECE ICP Forests Programme Co-ordinating Centre (2016) were followed.

The water budget model LWF-Brook90 (Version 3.4; Hammel and Kennel, 2001) was used to simulate soil water fluxes for all study sites except the NHB site, for which the CoupModel (Jansson and Karlberg, 2004) was applied. Both models demonstrated their potential in simulating unsaturated soil water fluxes using Richards' equation in many studies (Panferov et al., 2009; Baumgarten et al., 2014; Thiele et al., 2017; Schmidt-Walter et al., 2019). Due to a better fit between observed and modeled matrix potentials with CoupModel, we decided to choose the water fluxes from this model for the NHB site (Karl et al., 2012). With regard to the maximum slope inclination and the estimated infiltration capacities, we assumed that $\mathrm{N}$ losses from the plots through surface runoff are of subordinate importance. Due to permanently formed macropores and low bulk density providing complete infiltration of precipitation, surface runoff is generally rare in forest ecosystems (Jankiewicz et al., 2005; Neary et al., 2009). Meteorological data (precipitation, air temperature, humidity, global radiation, and wind speed) were ob- 
Table 1. Site and stand characteristics of seven European beech (Fagus sylvatica L.) forest ecosystems (reference year 2010). Site abbreviations are explained in the text.

\begin{tabular}{|c|c|c|c|c|c|c|c|}
\hline & $\mathrm{BBR}$ & FRE & EBR & NHB & GW & SOB & HOM \\
\hline Latitude (N) & $50^{\circ} 02^{\prime}$ & $48^{\circ} 24^{\prime}$ & $49^{\circ} 51^{\prime}$ & $50^{\circ} 24^{\prime}$ & $51^{\circ} 32^{\prime}$ & $51^{\circ} 46^{\prime}$ & $50^{\circ} 56^{\prime}$ \\
\hline Longitude (E) & $9^{\circ} 56^{\prime}$ & $11^{\circ} 39^{\prime}$ & $10^{\circ} 32^{\prime}$ & $7^{\circ} 43^{\prime}$ & $10^{\circ} 03^{\prime}$ & $9^{\circ} 35^{\prime}$ & $9^{\circ} 20^{\prime}$ \\
\hline Elevation (m a.s.1.) & 850 & 550 & 450 & 390 & 420 & 504 & 375 \\
\hline Slope $\left(^{\circ}\right)$ & 1.0 & 4.8 & 6.8 & 3.0 & 0.3 & 1.9 & 7.4 \\
\hline Mean temperature $\left({ }^{\circ} \mathrm{C}\right)$ & 6.0 & 8.3 & 7.7 & 8.3 & 7.4 & 6.9 & 7.3 \\
\hline Mean annual precipitation (mm) & 1048 & 845 & 783 & 971 & 712 & 1209 & 712 \\
\hline Stand age (years in 2010) & 134 & 157 & 94 & 117 & 142 & 163 & 141 \\
\hline Stand density $\left(\mathrm{N}\right.$, stems ha $\left.^{-1}\right)$ & 389 & 452 & 175 & 160 & 235 & 140 & 148 \\
\hline Mean diameter $\mathrm{Dg}(\mathrm{cm})$ & 36.1 & 32.6 & 49.4 & 50.6 & 47.9 & 48.5 & 51.9 \\
\hline Stand height $\mathrm{Hg}(\mathrm{m})$ & 26.5 & 29.4 & 32.5 & 37.8 & 35.5 & 30.1 & 39.8 \\
\hline Beech fraction of total basal area $(\%)$ & 100 & $66^{\mathrm{a}}$ & $91^{\mathrm{b}}$ & 100 & $91^{\mathrm{c}}$ & 100 & $94^{\mathrm{d}}$ \\
\hline Clay/silt/sand $(\%)(0-10 \mathrm{~cm})$ & $40 / 50 / 10$ & $16 / 60 / 24$ & $19 / 55 / 26$ & $23 / 38 / 39$ & $36 / 61 / 3$ & $20 / 49 / 31$ & $12 / 68 / 20$ \\
\hline Humus type & moder & mull & mull & moder & mull & moder & mull \\
\hline Parent material & basalt & $\begin{array}{l}\text { loess over upper } \\
\text { marine molasses }\end{array}$ & sandstone & $\begin{array}{l}\text { pumice } \\
\text { stone }\end{array}$ & limestone & $\begin{array}{l}\text { loess over } \\
\text { sandstone }\end{array}$ & basalt \\
\hline
\end{tabular}

a $34 \%$ Quercus robur. ${ }^{\mathrm{b}} 9 \%$ Quercus petraea. ${ }^{\mathrm{c}}$ Fraxinus, Acer, Quercus, Ulmus. ${ }^{\mathrm{d}}$ Picea abies.

Table 2. Chemical characteristics of foliage, soil organic layer, and the upper mineral soil $(0-10 \mathrm{~cm})$ of seven European beech $($ Fagus sylvatica L.) ecosystems.

\begin{tabular}{lrrrrrrr}
\hline & BBR & FRE & EBR & NHB & GW & SOB & HOM \\
\hline Foliage & & & & & & & \\
\left.\hline${\mathrm{N}\left(\mathrm{mg} \mathrm{g}^{-1}\right)}^{-1}\right)$ & 24.9 & 24.0 & 23.5 & 23.9 & 24.5 & 24.6 & 22.5 \\
$\mathrm{P}\left(\mathrm{mg} \mathrm{g}^{-1}\right)$ & 1.41 & 1.35 & 1.11 & 1.07 & 1.06 & 1.26 & 1.36 \\
$\mathrm{~N} / \mathrm{P}$ & 17.7 & 17.8 & 21.3 & 22.3 & 23.2 & 19.4 & 16.5 \\
\hline Organic layer & & & & & & & \\
\hline Mg Cha & & & & & & & \\
$\mathrm{C} / \mathrm{N}$ & 27 & 4 & 6 & 25 & 10 & 34 & 13 \\
$\mathrm{C} / \mathrm{P}$ & 19 & 26 & 26 & 24 & 23 & 19 & 25 \\
$\mathrm{~N} / \mathrm{P}$ & 262 & 372 & 503 & 418 & 397 & 378 & 356 \\
\hline Mineral soil $(0-10 \mathrm{~cm})$ & 14 & 14 & 19 & 17 & 17 & 20 & 14 \\
\hline $\mathrm{pH}\left(\mathrm{H}_{2} \mathrm{O}\right)$ & & & & & & & \\
$\mathrm{BS}(\%)$ & 4.3 & 4.4 & 3.9 & 4.5 & 6.1 & 3.6 & 4.2 \\
$\mathrm{C}(\%)$ & 42 & 24 & 26 & 14 & 98 & 7 & 58 \\
$\mathrm{~N}(\%)$ & 12.4 & 1.1 & 4.2 & 8.0 & 7.4 & 6.5 & 5.4 \\
$\mathrm{P}(\%)$ & 0.89 & 0.09 & 0.22 & 0.52 & 0.55 & 0.33 & 0.31 \\
$\mathrm{C} / \mathrm{N}$ & 0.19 & 0.03 & 0.02 & 0.11 & 0.05 & 0.05 & 0.04 \\
$\mathrm{C} / \mathrm{P}$ & 14 & 12 & 19 & 15 & 13 & 20 & 17 \\
$\mathrm{~N} / \mathrm{P}$ & 65 & 41 & 172 & 71 & 136 & 120 & 136 \\
\hline & 4.7 & 3.0 & 11.0 & 4.7 & 11.0 & 6.6 & 7.8 \\
\hline
\end{tabular}

tained from observations at the respective sites (Raspe et al., 2013) or regionalized from climate stations of the German Weather Service. For more methodical details and evaluation of model performance of regionalized climate data, see Ahrends et al. (2018).

The stand characteristics (e.g. stem diameter at $1.3 \mathrm{~m}$ $\mathrm{DBH}$, tree height, number of trees) were obtained for all trees with a $\mathrm{DBH}>7 \mathrm{~cm}$ by using forest inventories which were repeated at least every 5 years during the observation period and involved standardized silvicultural methods (Dobbertin and Neumann, 2016). We calculated the net $\mathrm{N}$ uptake for the aboveground tree increment $\left(N_{\mathrm{U}}\right)$ by multiplying the actual growth increment for each plant compartment (solid timber over bark above $7 \mathrm{~cm}$ diameter) with the content of nutrients in the respective compartment assuming that woody biomass is completely exported from the sites. Where site-specific 
$\mathrm{N}$ contents of tree compartments were missing, data from Jacobsen et al. (2003) were used. Biomass growth of each tree compartment was calculated as the sum of increment of standing trees between two forest inventories plus biomass losses due to logging. The biomass at each site and inventory was calculated from tree diameter, tree height, and number of standing and harvested trees using allometric biomass functions (e.g. Wutzler et al., 2008).

Net primary production (NPP) was estimated as a sum of annual biomass increase in wood and bark and total litterfall.

Net gaseous $\mathrm{N}$ exchange (NE) was measured with the closed chamber technique at three of the seven sites (Brumme and Borken, 2009; Eickenscheidt and Brumme, 2013). The SOB site was one of the few sites in Germany where high seasonal $\mathrm{N}_{2} \mathrm{O}$ emissions (1.92 $\pm 0.63 \mathrm{~kg} \mathrm{Nha}^{-1} \mathrm{yr}^{-1}$; Brumme and Borken, 2009) were observed. The GW site had low $\mathrm{N}_{2} \mathrm{O}$ emissions $\left(0.16 \pm 0.002 \mathrm{~kg} \mathrm{Nha}^{-1}\right)$, and the NHB site showed negative $\mathrm{N}_{2} \mathrm{O}$ emissions $\left(-0.10 \mathrm{~kg} \mathrm{Nha}^{-1}\right.$; Eickenscheidt and Brumme, 2013). Annual $\mathrm{NO}_{x}$ fluxes were also low at the NHB $\left(0.34 \mathrm{~kg} \mathrm{Nha}^{-1}\right)$ and SOB $\left(0.07 \mathrm{~kg} \mathrm{~N} \mathrm{ha}^{-1}\right)$ sites (Eickenscheidt and Brumme, 2013). Mean annual emission of $\mathrm{N}_{2} \mathrm{O}$ from deciduous forests with background emissions in Germany of $0.37 \mathrm{~kg} \mathrm{Nha}^{-1}$ were estimated by SchulteBisping et al. (2003). We assume that annual gaseous $\mathrm{N}$ output of $\mathrm{N}_{2} \mathrm{O}$ and $\mathrm{NO}_{x}$ from deciduous forests with background emissions of $0.58 \mathrm{~kg} \mathrm{~N} \mathrm{ha}^{-1}(0.37+(0.34+0.07) / 2)$ equals $N_{\mathrm{F}}$ (Posch et al., 2015). Thus net gaseous $\mathrm{N}$ emission $\left(N_{\mathrm{E}}-N_{\mathrm{F}}\right)$ is assumed to be negligible for all sites except at the SOB site where high seasonal $\mathrm{N}_{2} \mathrm{O}$ emissions were observed. For this site the annual emission of $\mathrm{N}_{2} \mathrm{O}$ and $\mathrm{NO}_{x}$ equals $1.99 \mathrm{~kg} \mathrm{~N} \mathrm{ha}^{-1}$, and after correcting for $N_{\mathrm{F}}$ a value of $1.41 \mathrm{~kg} \mathrm{~N} \mathrm{ha}^{-1}\left(1.99-0.58 \mathrm{~kg} \mathrm{ha}^{-1}\right)$ was used for net gaseous $\mathrm{N}$ emission.

Litterfall was collected from 1995-2005 at the site NHB in Rhineland-Palatinate, from 1995-2008 at Lower Saxonian sites, from 1998-2008 at sites in Bavaria, and from 1997-2008 at the Hessian site. Leaf litter included all tree species; in most cases it was beech only (Table 1). Eight to 12 litter traps, each with a surface area of 0.25 to $2 \mathrm{~m}^{2}$, were used (Ukonmaanaho et al., 2016). Litter was sorted differently at the different sites. At Lower Saxonian and Hessian sites, litterfall was separated into leaf litter, seeds, and a residual fraction which consists of cupules, twigs, and other small pieces. At Bavarian sites, litter was separated into three fractions, namely leaves, fruit components (seeds + cupules), and twigs. A residual fraction was included in the fruit fraction. At the stand NHB in Rhineland-Palatinate, and two other stands with European beech, KHB and NHQ, detailed fractionations and analyses of leaves, seeds, seed cupules, twigs, and residual small pieces were conducted.

The numbers of seeds were used to distinguish fructification intensity according to Burschel (1966). Years with more than 150 seeds per square meter were classified as a mast year and those with 100 to 150 seeds as a half-mast.
The numbers of seeds was only available for the sites in Rhineland-Palatinate. For the Hessian and Lower Saxonian study sites, we calculated the number of seeds from the measured dry weight $\left(\mathrm{g} \mathrm{DW} \mathrm{m}^{2} \mathrm{yr}^{-1}\right)$ of annual seed litterfall flux by assuming a single seed weight of $0.22 \mathrm{~g}(\mathrm{cv}=13 \%)$. This weight was determined by using a subsample of 300 seeds from these sites. The calculated value showed a good agreement with other studies (Kaliniewicz et al., 2015; Bezdeckova and Matejka, 2015). For Bavarian sites the seed mass was calculated by using a mean ratio between seeds and the sum of seeds + seed cupules of 0.14 for years without mast $(n=22)$ and a ratio of $0.37(n=11)$ for mast years. These ratios were derived from Rhineland-Palatinate (NHN, KHB, and NHQ sites) where the mass of seeds and cupules was separately measured between 1995 and 2005.

Foliar analyses were performed annually to characterize tree nutrition. Samples from 6 to 18 beech trees were taken from the light-exposed crown during full foliation and analyzed for all major nutrients (Rautio et al., 2016). In order to characterize soil nutrient availability and acid-base status, soil samples were collected about every 10 years at the monitoring sites. Procedures of soil sampling, transport, and storage as well as analytical methods were adapted from Cools and De Vos (2016).

\subsection{2 $\quad{ }^{15} \mathrm{~N}$-labeled leaf litter exchange experiment}

The ${ }^{15} \mathrm{~N}$-labeled litter exchange experiment was established in May 2006 at the study sites. Leaf litter from the beech forests was exchanged by ${ }^{15} \mathrm{~N}$-labeled litter $(1.3 \%-6.9 \%$ ${ }^{15} \mathrm{~N}$ ), collected from beech trees grown in a greenhouse that received ${ }^{15} \mathrm{~N}$-enriched solution in the irrigation water. PVC rings (diameter of $26.6 \mathrm{~cm}$ ) were fixed at the soil surface to create the plots. After removing the loose L litter inside each ring, it was replaced with $17 \mathrm{~g}$ of ${ }^{15} \mathrm{~N}$-labeled litter. A wire netting was used to keep the leaves in the PVC rings until the following litterfall. At the end of the exposure 5.5 years after the start of the experiment in November 2011, the number of PVC rings sampled was two at the BBR and HOM sites; four at the EBR, FRE, and GW sites; and five at the NHB and SOB sites. The litter layers were collected separately from each PVC ring (L layer sample). Soil samples were taken from inside the PVC ring using a stainless-steel tube (diameter $8 \mathrm{~cm}$ ) down to $20 \mathrm{~cm}$ depth and a soil corer (diameter $2 \mathrm{~cm}$ ) from 20 to $40 \mathrm{~cm}$ soil depth. Soil columns were divided into layers of 1 to $10 \mathrm{~cm}$ thickness. Individual samples from each site were mixed for each soil layer. Additional soil samples were taken at the sites for all depths to determine the natural ${ }^{15} \mathrm{~N}$ abundance of $\mathrm{N}\left({ }^{15} \mathrm{~N}_{\mathrm{na}}\right)$. All soil samples were sieved to $2 \mathrm{~mm}$, ground, and analyzed for total $\mathrm{N}$, total $\mathrm{C}$, and ${ }^{15} \mathrm{~N}$ with an element analyzer coupled with an IRMS (isotopic ratio mass spectrometer, Finnigan MAT, Bremen, Germany) at KOSI Laboratory, Göttingen.

Nitrogen consists of two stable atoms, ${ }^{14} \mathrm{~N}(99.634 \%)$ and ${ }^{15} \mathrm{~N}(0.366 \%)$. During $\mathrm{N}$ transformation processes, the ratio 
${ }^{14} \mathrm{~N} /{ }^{15} \mathrm{~N}$ may change due to isotopic discrimination. For an accurate estimation of the recovery of added ${ }^{15} \mathrm{~N}$ in labeling experiments, ${ }^{15} \mathrm{~N}_{\mathrm{na}}$ is needed. The ${ }^{15} \mathrm{~N}_{\mathrm{na}}$ of the samples of the sites ranged from $0.365 \%$ in the L layer to $0.368 \%$ in $30-40 \mathrm{~cm}$ soil. The recovery of the added ${ }^{15} \mathrm{~N}$ in a labeling experiment ${ }^{15} \mathrm{~N}_{\mathrm{ex}}(\%)$ is calculated by subtracting ${ }^{15} \mathrm{~N}_{\text {na }}$ from the measured enrichment of ${ }^{15} \mathrm{~N}_{\mathrm{S}}$ in the samples $\left({ }^{15} \mathrm{~N}_{\mathrm{ex}}={ }^{15} \mathrm{~N}_{\mathrm{S}}-{ }^{15} \mathrm{~N}_{\mathrm{na}}(\%)\right)$.

\subsection{Statistical analysis}

The relationships between two variables were tested by using Spearman correlation coefficients $\left(r_{\text {Spear }}\right)$ because this measure makes no assumption about the distribution of the variables and the linearity of the relations (Rhodes et al., 2009). For graphical presentation of the relationship between recovery of leaf litter $\mathrm{N}$ and some variables (e.g. litterfall), linear regression functions were calculated. In order to confirm the results of linear regression analyses, which are assumed to be quite uncertain due to the small sample sizes, $r_{\text {Spear }}$ values were calculated as well. In addition, the coefficient of variation (cv \%) was estimated as the ratio of standard deviation and arithmetic mean. All statistical analyses were performed using R version 3.5.2 (R Development Core Team, 2017).

\section{Results}

\subsection{Biomass production, foliar nutrients, and litterfall}

Mean annual aboveground net primary production (NPP) of the seven sites amounted to $11.8 \mathrm{Mg}$ dry mass ha $^{-1}$ (cv 25\%) out of which $57 \%$ was contributed by tree increment and $43 \%$ by total litterfall (Table 3 ). Tree $\mathrm{N}$ increment showed a negative correlation with the $\mathrm{C} / \mathrm{N}$ ratio of the mineral soil $(0-10 \mathrm{~cm})\left(r_{\text {Spear }}=-0.82, p<0.05\right)($ Fig. 5). Mean annual leaf litterfall of the stands was $3.12 \mathrm{Mg} \mathrm{ha}^{-1}$ (cv 13\%) and contributed $61 \%$ to the mean annual total litterfall of $5.11 \mathrm{Mg} \mathrm{ha}^{-1}$ (cv $\left.11 \%\right)$. Leaf litterfall was closely related to tree increment and total litterfall (Table 6; Fig. 5). The recurrence interval of mast production was 2.0 years if halfmasts were included. Years with a full-mast occurred once every 2.7 years. Particularly in the years 2000, 2002, 2004, and 2006, full- and half-mast were synchronous in almost every stand (Fig. 1). No mast event occurred in 1996, 1997, 2005, or 2008. Mast frequency was highest at the FRE and EBR sites. The biggest increase in total litterfall due to mast occurred at the HOM site $(+101 \%)$. In the mast years, mean annual litter production increased by $2.01 \mathrm{Mg} \mathrm{ha}^{-1}$ to an average of $6.1 \mathrm{Mg} \mathrm{ha}^{-1}$ (cv 15\%) when compared to the nonmast years. The difference in the amount of total litterfall between years with and without mast was the result of seed and seed cupule production as well as of the changes in other fractions induced by fructification. The mean change in the leaf fraction was $+1.3 \%$ (Table 3). Detailed fractionation and analysis of leaves, seeds, seed cupules, twigs, and resid-

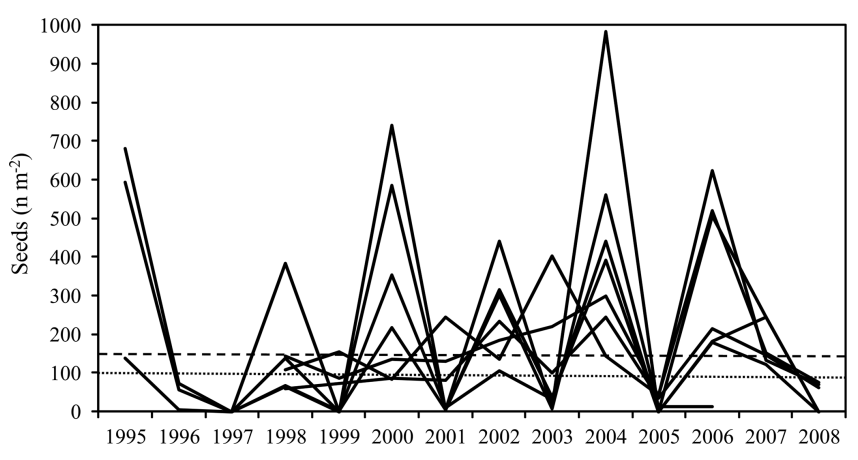

Figure 1. Production of seeds (seeds per square meter) at the study sites. Horizontal lines indicate years with half-mast (100-149 seeds per square meter - dotted line) and full-mast ( $\geq 150$ seeds per square meter - dashed line).

ual small pieces at three sites in Rhineland-Palatinate indicated a change of $+3.3 \%$ in the leaf fraction, $+11 \%$ in the twig fraction, and a big change of $+32 \%$ in the residual fraction, pointing to an increase in the production of small pieces in the mast (Table 4).

The mean annual $\mathrm{N}$ flux with total litterfall amounted to $58.6 \mathrm{~kg} \mathrm{ha}^{-1}$ (cv $8 \%$ ) of which $34.6 \mathrm{~kg} \mathrm{ha}^{-1}$ (cv 10\%) was contributed by leaf litter (Table 3 ). In mast years total litterfall $\mathrm{N}$ increased to $74.2 \mathrm{~kg} \mathrm{ha}^{-1}$ in contrast to leaf litterfall, which contributed almost the same amount of $\mathrm{N}\left(36.3 \mathrm{~kg} \mathrm{ha}^{-1}\right)$. Mast increased the total litterfall $\mathrm{N}$ by $32.4 \mathrm{~kg} \mathrm{ha}^{-1}$ when compared with non-mast years. In a similar way to dry mass, mean annual $\mathrm{N}$ fluxes with leaf, twig, and residual fractions increased by $11 \%-11.7 \%, 14 \%$, and $49 \%$, respectively, in the mast years (Tables 3,4 ).

Dry mass of seed cupules was twice that of seeds for an observation period of 11 years (Table 4). Despite a higher mass of seed cupules, fluxes of N, P, and sulfur (S) with seed cupules were low. Due to their low N content, seed cupules contributed only $2 \mathrm{~kg} \mathrm{ha}^{-1} \mathrm{yr}^{-1}$ of $\mathrm{N}$ to total litterfall when compared with seeds $\left(8 \mathrm{~kg} \mathrm{~N} \mathrm{ha}^{-1} \mathrm{yr}^{-1}\right)$. The low $\mathrm{N}$ content of seed cupules resulted in very high mean $\mathrm{C} / \mathrm{N}$ ratio of 144 when compared to a mean $\mathrm{C} / \mathrm{N}$ ratio of 19 in seeds. Seed cupules also had very high $\mathrm{C} / \mathrm{P}$ and $\mathrm{C} / \mathrm{S}$ ratios.

At all the study sites foliar $\mathrm{N}$ concentrations of beech trees were similar, whereas $\mathrm{P}$ concentrations differed (Table 2). Beech stands on unconsolidated sandy substrates, limestone, and pumice stone (Table 1) with low soil P contents showed lower foliar $\mathrm{P}$ and higher foliar $\mathrm{N} / \mathrm{P}$ ratios than those on basaltic rock or loess.

\subsection{Recovery of ${ }^{15} \mathrm{~N}$-labeled leaf litter $\mathrm{N}$ in the soil}

The highest enrichment of the added ${ }^{15} \mathrm{~N}$-labeled leaf litter in the soil profiles of seven beech forests after 5.5 years of litter exchange was found in $2-4 \mathrm{~cm}$ depth of the organic layers in soils with moder-type humus (BBR, NHB, SOB) and in $3-10 \mathrm{~cm}$ in the mineral soils with mull-type humus 
Table 3. Aboveground annual net primary production (NPP) and annual tree increment (INCR) $\left(\mathrm{Mg}\right.$ dry mass ha ${ }^{-1}$ ) at the study sites during the period 1995-2008. Annual means of dry weight $\left(\mathrm{Mg} \mathrm{ha}^{-1}\right)$ and nitrogen $\left(\mathrm{kg} \mathrm{ha}^{-1}\right)$ of total litterfall (TLF) and leaf litterfall (LLF) for all years (overall mean), for years with mast (full- and half-mast) (MY), for non-mast years (NMY), and the difference between mast and non-mast years (change \%) for seven beech forests. Years with mast (full-mast years in bold) and the number of mast and non-mast years and years between mast events are given for the study sites.

\begin{tabular}{|c|c|c|c|c|c|c|c|c|c|c|c|c|c|c|c|c|}
\hline & \multicolumn{2}{|c|}{ Mean } & \multicolumn{2}{|c|}{ BBR } & \multicolumn{2}{|c|}{ FRE } & \multicolumn{2}{|c|}{ EBR } & \multicolumn{2}{|c|}{ NHB } & \multicolumn{2}{|c|}{ GW } & \multicolumn{2}{|c|}{ SOB } & \multicolumn{2}{|c|}{ HOM } \\
\hline & TLF & LLF & TLF & LLF & TLF & LLF & TLF & LLF & TLF & LLF & TLF & LLF & TLF & LLF & TLF & LLF \\
\hline \multicolumn{17}{|l|}{ Dry mass } \\
\hline NPP & \multirow{2}{*}{\multicolumn{2}{|c|}{$\begin{array}{c}11.80 \\
6.69\end{array}$}} & \multirow{2}{*}{\multicolumn{2}{|c|}{$\begin{array}{c}10.49 \\
6.19\end{array}$}} & \multirow{2}{*}{\multicolumn{2}{|c|}{$\begin{array}{c}14.59 \\
8.94\end{array}$}} & \multirow{2}{*}{\multicolumn{2}{|c|}{$\begin{array}{l}7.58 \\
2.80\end{array}$}} & \multirow{2}{*}{\multicolumn{2}{|c|}{$\begin{array}{c}14.86 \\
9.75\end{array}$}} & \multirow{2}{*}{\multicolumn{2}{|c|}{$\begin{array}{c}10.67 \\
5.74\end{array}$}} & \multirow{2}{*}{\multicolumn{2}{|c|}{$\begin{array}{l}9.65 \\
4.61\end{array}$}} & \multirow{2}{*}{\multicolumn{2}{|c|}{$\begin{array}{c}14.75 \\
8.80\end{array}$}} \\
\hline INCR & & & & & & & & & & & & & & & & \\
\hline Overall mean & 5.11 & 3.12 & 4.30 & 2.86 & 5.65 & 3.88 & 4.78 & 2.76 & 5.11 & 3.44 & 4.93 & 2.95 & 5.04 & 2.89 & 5.95 & 3.09 \\
\hline MY & 6.10 & 3.15 & 5.07 & 2.86 & 6.05 & 3.90 & 5.27 & 2.79 & 6.28 & 3.67 & 6.12 & 2.97 & 5.96 & 2.85 & 7.94 & 3.03 \\
\hline NMY & 4.09 & 3.11 & 3.86 & 2.86 & 4.60 & 3.80 & 3.64 & 2.70 & 4.44 & 3.41 & 4.03 & 2.94 & 4.11 & 2.94 & 3.95 & 3.14 \\
\hline MY - NMY & 2.01 & 0.04 & 1.21 & 0 & 1.45 & 0.10 & 1.63 & 0.09 & 1.84 & 0.26 & 2.09 & 0.03 & 1.85 & -0.09 & 3.99 & -0.11 \\
\hline Change (\%) & +49 & +1.3 & +31 & \pm 0 & +32 & 2.6 & +45 & +3.3 & +41 & +7.6 & +52 & +1.0 & +45 & -3.1 & +101 & -3.5 \\
\hline \multicolumn{17}{|l|}{ Nitrogen } \\
\hline Overall mean & 58.6 & 34.6 & 52.5 & 35.0 & 62.6 & 39.1 & 53.5 & 29.3 & 56.9 & 38.0 & 56.8 & 33.7 & 63.8 & 34.8 & 64.3 & 32.3 \\
\hline MY & 74.2 & 36.3 & 65.5 & 34.4 & 70.7 & 41.0 & 61.9 & 31.4 & 72.3 & 42.3 & 75.5 & 35.6 & 82.8 & 36.1 & 90.6 & 33.2 \\
\hline NMY & 41.8 & 32.5 & 45.1 & 35.4 & 41.1 & 34.1 & 32.9 & 23.9 & 48.1 & 36.8 & 42.8 & 32.4 & 44.8 & 33.5 & 37.9 & 31.3 \\
\hline MY - NMY & 32.4 & 3.8 & 20.4 & -1.0 & 29.6 & 6.9 & 29.0 & 7.5 & 24.2 & 5.5 & 32.7 & 3.2 & 38.0 & 2.6 & 52.7 & 1.90 \\
\hline Change (\%) & +77 & +11.7 & +45 & -2.8 & +72 & 20 & +88 & +31 & +50 & +15 & +76 & +10 & +85 & +7.8 & +139 & +6.1 \\
\hline Mast years & & & $\begin{array}{l}2002, \\
2006,\end{array}$ & $\begin{array}{l}\mathbf{2 0 0 4} \\
2007\end{array}$ & $\begin{array}{c}1998, \\
2001, \\
\mathbf{2 0 0 3}, \\
\mathbf{2 0 0 6}\end{array}$ & $\begin{array}{l}\mathbf{1 9 9 9}, \\
2002, \\
2004, \\
2007\end{array}$ & $\begin{array}{l}1998, \\
2001, \\
\mathbf{2 0 0 3}, \\
\mathbf{2 0 0 6}\end{array}$ & $\begin{array}{l}2000, \\
\mathbf{2 0 0 2}, \\
\mathbf{2 0 0 4}, \\
2007\end{array}$ & $\begin{array}{l}1995, \\
\mathbf{2 0 0 2}\end{array}$ & $\begin{array}{l}2000 \\
2004\end{array}$ & $\begin{array}{r}\mathbf{1 9 9 5} \\
2002 \\
\mathbf{2 0 0 6}\end{array}$ & $\begin{array}{l}\mathbf{2 0 0 0}, \\
\mathbf{2 0 0 4}, \\
2007\end{array}$ & $\begin{array}{r}1995 \\
2000 \\
2004 \\
2\end{array}$ & $\begin{array}{l}1998, \\
\mathbf{2 0 0 2}, \\
\mathbf{2 0 0 6}, \\
07\end{array}$ & $\begin{array}{l}1998 \\
2002 \\
2006\end{array}$ & $\begin{array}{l}2000 \\
2004, \\
2007\end{array}$ \\
\hline Number of MYs & \multicolumn{2}{|c|}{43} & \multicolumn{2}{|c|}{4} & \multicolumn{2}{|c|}{8} & \multicolumn{2}{|c|}{8} & \multicolumn{2}{|c|}{4} & \multicolumn{2}{|c|}{6} & & 7 & \multicolumn{2}{|c|}{6} \\
\hline Number of NMYs & \multicolumn{2}{|c|}{42} & \multirow{2}{*}{\multicolumn{2}{|c|}{7}} & \multirow{2}{*}{\multicolumn{2}{|c|}{3}} & \multirow{2}{*}{\multicolumn{2}{|c|}{3}} & \multirow{2}{*}{\multicolumn{2}{|c|}{$\begin{array}{c}8 \\
3.0\end{array}$}} & \multirow{2}{*}{\multicolumn{2}{|c|}{$\begin{array}{c}8 \\
2.3\end{array}$}} & & 7 & & \\
\hline$(\mathrm{MY}+\mathrm{NMY}) / \mathrm{MY}$ & & 0 & & & & & & & & & & & & 0 & & \\
\hline
\end{tabular}

(FRE, EBR, GW, HOM) (Fig. 2). In the 0 to $1 \mathrm{~cm}$ and 30 to $40 \mathrm{~cm}$ layers the enrichment was lower than $1 \%$. No labeled ${ }^{15} \mathrm{~N}$ was found in the L layers except at the HOM site. The recovery of labeled ${ }^{15} \mathrm{~N}$ ranged from $32 \%$ to $72 \%$ in the upper $40 \mathrm{~cm}$ depth of the soils (mean value $48 \% \pm 5 \%$ ). This equals an average recovery of leaf litter $\mathrm{N}$ of $17 \mathrm{~kg} \mathrm{ha}^{-1}$ after 5.5 years, about half of the mean annual leaf litterfall $\mathrm{N}$ of the seven sites (34.6 $\mathrm{kg} \mathrm{N} \mathrm{ha}^{-1}$, Table 3). Sites with a low recovery of ${ }^{15} \mathrm{~N}$ in the organic layer exhibited higher recovery in the mineral soil and vice versa (Fig. 2). The recovered leaf litter $\mathrm{N}$ significantly increased with total litterfall dry mass and total litterfall $\mathrm{N}$ but not with leaf litterfall dry mass and leaf litterfall N (Fig. 3; Table 6).

\subsubsection{N fluxes and $\mathrm{N}$ budgets}

Total $\mathrm{N}$ deposition $\left(N_{\mathrm{D}}\right)$ was quite similar at all sites, whereas net uptake for aboveground tree $\mathrm{N}$ increment $\left(N_{\mathrm{U}}\right)$ and seepage $\mathrm{N}$ output $\left(N_{\mathrm{L}}\right)$ differed considerably (Table 5$)$. Annual total $\mathrm{N}$ deposition ranged from 18 to $24 \mathrm{~kg} \mathrm{ha}^{-1}$ from 1994 to 2008 , and annual tree $\mathrm{N}$ increment ranged between 4.4 and $14.2 \mathrm{~kg} \mathrm{Nha}^{-1}$. The mean annual total $\mathrm{N}$ deposition of $20.7 \mathrm{~kg} \mathrm{ha}^{-1}$ (cv 9\%) was about twice as high as for tree $\mathrm{N}$ increment (10.1 $\mathrm{kg} \mathrm{Nha}^{-1}$ ) (cv $\left.34 \%\right)$. Annual seepage $\mathrm{N}$ output was relatively low $\left(4.8 \mathrm{~kg} \mathrm{ha}^{-1}\right.$; cv $\left.83 \%\right)$, with values ranging from 0.8 to $6.6 \mathrm{~kg} \mathrm{ha}^{-1}$ except at the BBR site,

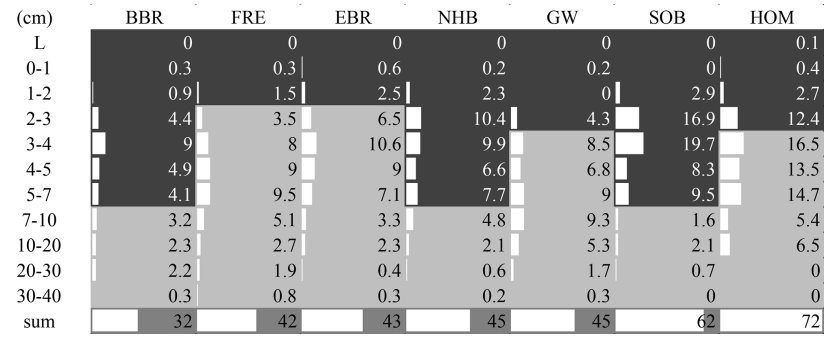

Figure 2. Recovered ${ }^{15} \mathrm{~N}$-labeled leaf litter $\left(\%{ }^{15} \mathrm{~N}_{\text {excess }}\right.$ recovery per plot) within the soils after 5.5 years of leaf litter exchange at seven European beech (Fagus sylvatica L.) sites. The organic layer $(>15 \% \mathrm{C})$ is indicated by dark grey filled area and mineral soil by light grey filled area. L: loose leaf litter.

where $12 \mathrm{~kg} \mathrm{Nha}^{-1} \mathrm{yr}^{-1}$ was lost with seepage water. Seepage $\mathrm{N}$ output from the soil was positively correlated with $\mathrm{C}$ $\left(r_{\text {Spear }}=0.93, p<0.01\right), \mathrm{N}\left(r_{\text {Spear }}=0.96, p<0.01\right)$ and $\mathrm{P}$ content $\left(r_{\text {Spear }}=0.86, p<0.05\right)$ as well as with the clay content in the mineral soil $(0-10 \mathrm{~cm})\left(r_{\text {Spear }}=0.96, p<\right.$ $0.01)$ (Fig. 5). The clay content was also positively related to the $\mathrm{C}\left(r_{\text {Spear }}=0.86, p<0.05\right), \mathrm{N}\left(r_{\text {Spear }}=0.89, p<0.01\right)$, and $\mathrm{P}$ content $\left(r_{\text {Spear }}=0.82, p<0.01\right)$ of the mineral soil.

Changes in the soil $\mathrm{N}$ pool, which were calculated by input-output analysis $\left(\Delta \mathrm{N}_{\mathrm{S}}\right.$, Eq. 1), indicated an annual soil 
Table 4. Annual means of dry weight $\left(\mathrm{Mg} \mathrm{ha}^{-1}\right)$, nitrogen $(\mathrm{N})$, phosphorous $(\mathrm{P})$, and sulfur $(\mathrm{S})\left(\mathrm{kg} \mathrm{ha}^{-1}\right)$ of litter fractions $($ leaf litter, seeds, seed cupules, twigs, total litterfall, and a fraction of small pieces which were not separated (residual)), and the ratios of the elements at three European beech (Fagus sylvatica L.) stands in Rhineland-Palatinate from 1995-2005 (Neuhäusel Bims, NHB; Kirchheimbolanden, KHB; Neuhäusel Quarz, NHQ). For the dry mass and nitrogen, additional means are listed for years with mast (MY) (full- and half-mast), non-mast years (NMY), and the difference between mast and non-mast years. The changes of dry mass and $\mathrm{N}$ of litter fractions and total litterfall in mast years compared to non-mast years are given in percent.

\begin{tabular}{lrrrrrr}
\hline & Leaf litter & Seeds & Cupules & Twigs & Residual & Total litterfall \\
\hline Dry mass & & & & & & \\
\hline Overall mean $(n=33)$ & 3.24 & 0.29 & 0.59 & 0.29 & 0.47 & 4.87 \\
MY $(n=11)$ & 3.32 & 0.78 & 1.30 & 0.31 & 0.56 & 6.27 \\
NMY $(n=22)$ & 3.21 & 0.04 & 0.23 & 0.28 & 0.43 & 4.18 \\
MY - NMY & 0.11 & 0.75 & 1.07 & 0.03 & 0.14 & 2.09 \\
Change $(\%)$ & +3.3 & +2059 & +457 & +11 & +32 & +50 \\
\hline Nitrogen & & & & & & \\
\hline Overall mean & 37.0 & 8.0 & 2.0 & 2,5 & 6.6 & 56.1 \\
MY & 39.7 & 22.2 & 4.0 & 2.8 & 8.7 & 77.0 \\
NMY & 35.9 & 0.9 & 0.9 & 2.4 & 5.8 & 45.9 \\
MY - NMY & 3.8 & 21.3 & 3.1 & 0.3 & 2.9 & 31.1 \\
Change $(\%)$ & +11 & +2412 & +331 & +14 & +49 & +68 \\
P & 2.1 & 0.73 & 0.21 & 0,14 & 0.41 & 3.48 \\
S & 3.4 & 0.46 & 0.19 & 0,19 & 0.48 & 4.69 \\
C/N & 43 & 19 & 144 & 58 & 34 & 43 \\
C/P & 747 & 209 & 1358 & 1067 & 550 & 663 \\
C/S & 472 & 332 & 1475 & 765 & 470 & 511 \\
N/P & 17 & 11 & 9 & 18 & 16 & 16 \\
N/S & 11 & 17 & 10 & 13 & 14 & 12 \\
\hline
\end{tabular}

Table 5. Average total $\mathrm{N}$ deposition $\left(N_{\mathrm{D}}\right)$, tree $\mathrm{N}$ increment $\left(N_{\mathrm{U}}\right)$, net gaseous $\mathrm{N}$ emission $\left(N_{\mathrm{E}}-N_{\mathrm{F}}\right)$, seepage $\mathrm{N}$ outputs $\left(N_{\mathrm{L}}\right)$, and soil $\mathrm{N}$ pool change $\left(\Delta N_{S}\right.$, calculated from Eq. 1) for the period 1994 to 2008 and ${ }^{15} \mathrm{~N}$ recovery of applied labeled ${ }^{15} \mathrm{~N}$ with leaf litter of seven European beech (Fagus sylvatica L.) forest ecosystems. The ${ }^{15} \mathrm{~N}$ recovery 5.5 years after litter exchange is given in percent of applied ${ }^{15} \mathrm{~N}_{\text {excess }}$ and in $\mathrm{kg} \mathrm{ha}^{-1}$ of $\mathrm{N}$ of mean annual leaf litterfall $\mathrm{N}$.

\begin{tabular}{|c|c|c|c|c|c|c|c|}
\hline \multirow[t]{2}{*}{ Site } & $\begin{array}{r}\text { Total N } \\
\text { deposition }\end{array}$ & $\begin{array}{r}\text { Tree N } \\
\text { increment }\end{array}$ & $\begin{array}{l}\text { Net gaseous } \\
\text { N emission }\end{array}$ & $\begin{array}{l}\text { Seepage } \\
\mathrm{N} \text { output }\end{array}$ & $\begin{array}{r}\text { Soil N } \\
\text { pool change }\end{array}$ & \multicolumn{2}{|c|}{$\begin{array}{l}\text { Recovery of } \\
{ }^{15} \mathrm{~N}_{\text {excess }}\end{array}$} \\
\hline & & & $\mathrm{kg} \mathrm{Nha}^{-1} \mathrm{yr}^{-1}$ & & & $\%$ & $\mathrm{~kg} \mathrm{Nha}^{-1}$ \\
\hline BBR & 20.5 & 9.4 & 0 & 12.0 & -0.9 & 32 & 11 \\
\hline FRE & 17.9 & 14.2 & 0 & 0.8 & 2.9 & 43 & 17 \\
\hline EBR & 19.4 & 4.4 & 0 & 2.3 & 12.7 & 43 & 13 \\
\hline NHB & 21.7 & 11.8 & 0 & 6.5 & 3.4 & 45 & 17 \\
\hline GW & 21.1 & 11.2 & 0 & 6.6 & 3.3 & 45 & 15 \\
\hline SOB & 23.8 & 7.0 & 1.4 & 4.3 & 11.2 & 59 & 21 \\
\hline HOM & 20.8 & 12.9 & 0 & 0.9 & 7.0 & 72 & 23 \\
\hline Mean & 20.7 & 10.1 & & 4.8 & 5.7 & & 17 \\
\hline
\end{tabular}

$\mathrm{N}$ retention of 2.9 to $12.7 \mathrm{~kg} \mathrm{ha}^{-1}$ in six soils and a loss of $\mathrm{N}$ from the soil of $0.9 \mathrm{~kg} \mathrm{ha}^{-1} \mathrm{yr}^{-1}$ at the BBR site. On average $5.7 \mathrm{~kg} \mathrm{~N} \mathrm{ha}^{-1}$ (cv $86 \%$ ) was retained annually in soils. $\mathrm{N}$ retention in the soil increased with the $\mathrm{N} / \mathrm{P}$ ratio in the organic layer and the $\mathrm{C} / \mathrm{P}$ ratio of the upper mineral soil $(0-10 \mathrm{~cm})$ (Figs. 4,5 ). In total $15.8 \mathrm{~kg} \mathrm{~N}^{-1}$ was annually retained by trees and soils in the European beech ecosystems.

\section{Discussion}

\subsection{Frequency of fructification, biomass production, and $\mathbf{N}$ demand}

The production of seeds on the experimental sites was highly synchronized among different years (Fig. 1) as was ob- 

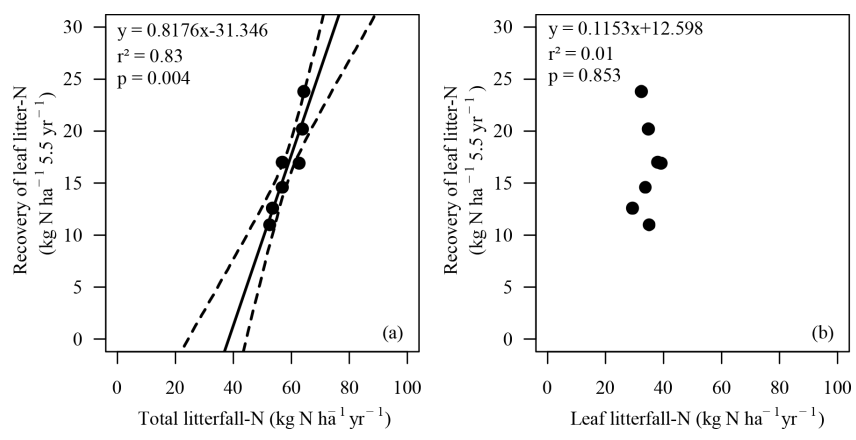

Figure 3. Recovery of leaf litter $\mathrm{N}\left(\mathrm{kg} \mathrm{ha}^{-1} \mathrm{yr}^{-1}\right)$ calculated from ${ }^{15} \mathrm{~N}$-labeled beech litter 5.5 years after litter exchange versus $\mathrm{N}$ flux with (a) total litterfall $\mathrm{N}$ and (b) with leaf litterfall $\mathrm{N}\left(\mathrm{kg} \mathrm{Nha}^{-1} \mathrm{yr}^{-1}\right)$ at the study sites $(n=7)$. Solid line: regression line. Dotted lines: confidence bands of regression with $p=$ 0.90. Spearman's rank correlation (a) $r_{\text {Spear }}=0.96, p<0.001$; (b) $r_{\text {Spear }}=0.00, p=1.0$.
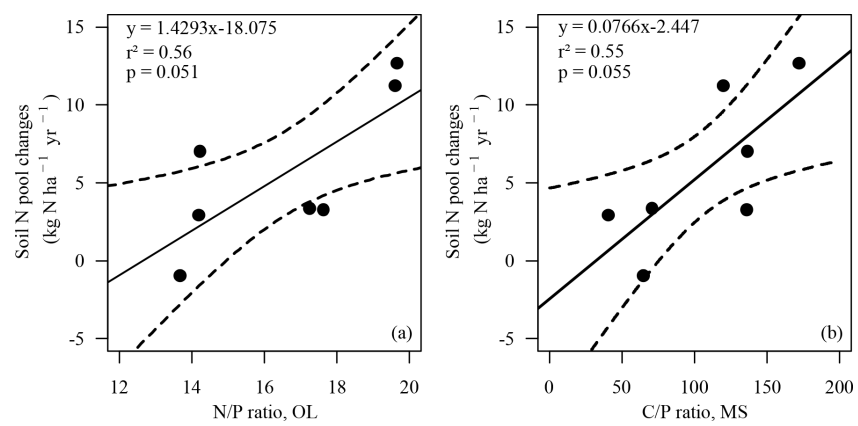

Figure 4. Soil $\mathrm{N}$ pool changes $\left(\Delta \mathrm{N}_{\mathrm{S}}, \mathrm{kg} \mathrm{Nha}^{-1} \mathrm{yr}^{-1}\right)$ versus $\mathrm{N} / \mathrm{P}$ ratio in the organic layer (OL) (a) and versus the $\mathrm{C} / \mathrm{P}$ ratio in the upper mineral soil $(0-10 \mathrm{~cm})(\mathrm{MS})(\mathbf{b})$. Solid line: regression line. Dotted lines: confidence bands of regression with $p=0.90$. Spearman's rank correlation (a) $r_{\text {Spear }}=0.86, p<0.05$; (b) $r_{\text {Spear }}=$ $0.79, p=<0.05$.

served by several authors (e.g. Wachter, 1964; Nussbaumer et al., 2016; Reil et al., 2015). It may be related to the selfincompatibility of beech, which therefore depends on crosswind pollination to produce seeds (Nielsen and De Muckadeli, 1954). A high frequency of a heavy mast (full- and half-mast) every 1.4 to 3.0 years (mean 2.0) in our seven study beech forests from 1995 to 2008 (Table 3) confirmed the prior reports by Paar et al. (2011) for Germany, by Övergaard et al. (2007) for Sweden, and by Lebourgeois et al. (2018) for France. They reported that the mast occurred every 2 to 3 years between 1974 and 2009. Visual ratings of fruiting at plots of the ICP Forest Level I and Level II networks showed a mast frequency of 2.6 to 5.5 years in Great Britain, Switzerland, Denmark, Germany, and Belgium (Nussbaumer et al., 2016). Such short mast intervals were not observed before the 1960s. Most authors reported mast frequencies of 5 to 10 years during the end of the 17th century up to the 1960s (Hase, 1964; Wachter, 1964; Övergaard et

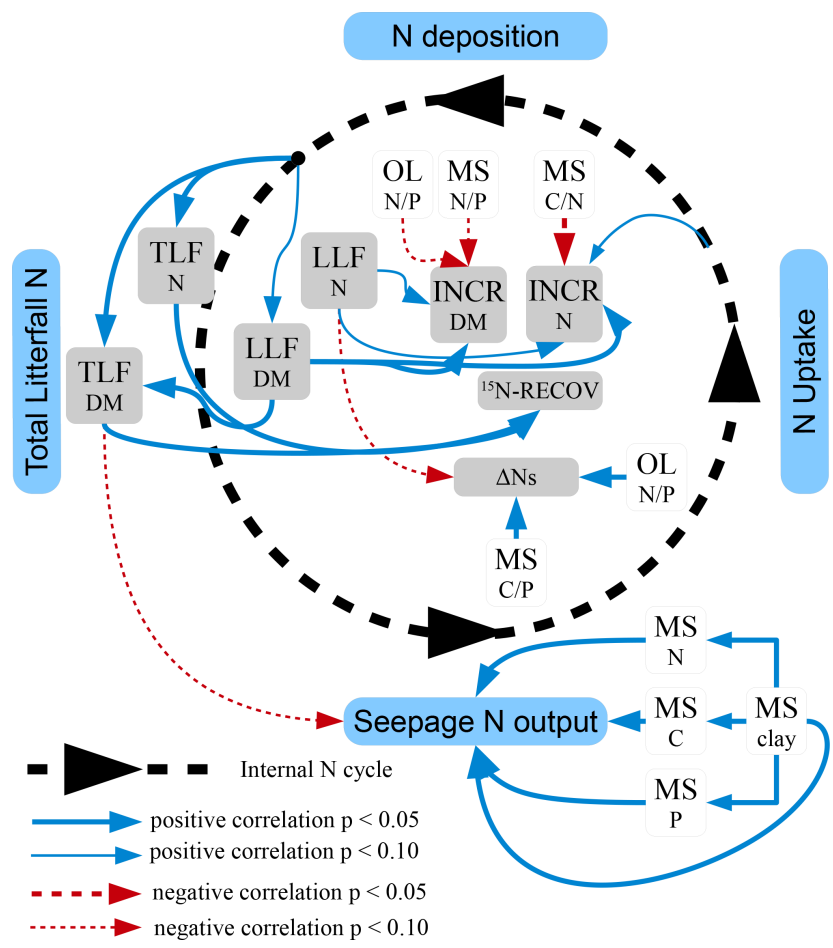

Figure 5. Schematic view of the detected effects of $\mathrm{N}$ uptake, total litterfall (TLF), leaf litterfall (LLF), and soil properties of the organic layer (OL) and the mineral soil (MS) on the $\mathrm{N}$ retention by tree increment (INCR), the soil $\mathrm{N}$ pool change $\left(\Delta \mathrm{N}_{\mathrm{S}}\right)$, the leaf ${ }^{15} \mathrm{~N}$ recovery $\left({ }^{15} \mathrm{~N}\right.$ RECOV), and the seepage $\mathrm{N}$ output. Significant positive correlations (Spearman correlation coefficients) are indicated by continuous arrows and negative correlations by dashed arrows. Other significant correlations with site and stand characteristics or the chemical characteristics were not found. Width of the line is proportional to the significance. Significant correlations $(p<0.05)$; tendency of correlations $(p<0.1)$.

al., 2007; Paar et al., 2011). Two such studies using historic data and litterfall measurements indicated an increase in the frequency of fructification. Övergaard et al. (2007) observed that the mean mast year interval was about 5 years from the end of the 17th century up to the 1960s but decreased to 2.5 years between 1974 and 2006 in southern Sweden. Paar et al. (2011) calculated that a mean interval of 4.7 years for full- and half-masts between 1839 and 1987 decreased to 2.6 years. This was obtained from the results of litterfall observations at 10 ICP Forests Level II plots between 1988 and 2010 in Lower Saxony and Hesse, Germany. Thus, a doubling of mast frequency in recent times occurred at least in Germany and southern Sweden.

The annual amount of leaf litterfall ranged from 2.76 to $3.88 \mathrm{Mg} \mathrm{ha}^{-1}$ (Table 3 ) and was in the same order of magnitude ( 2.95 to $3.33 \mathrm{Mg} \mathrm{ha}^{-1}$ ) as in 36 old-growth forest stands of Fagus sylvatica across a broad gradient of soil fertility covering nine mesozoic and kaenozoic parent material types (three limestones, two sandstones, two clay stones, one sand, 
Table 6. Correlation analyses (Spearman correlation coefficients, $r_{\text {Spear }}, p$ ) between leaf $\mathrm{N}$ recovery, total litterfall, leaf litterfall, and the input and output fluxes of nitrogen $(\mathrm{N})$ and biomass (DM, dry mass). Significant correlations $(p<0.05)$ are indicated by bold numbers.

\begin{tabular}{|c|c|c|c|c|c|c|}
\hline & \multicolumn{2}{|c|}{ Leaf $\mathrm{N}$ recovery } & \multicolumn{2}{|c|}{ Total litterfall } & \multicolumn{2}{|c|}{ Leaf litterfall } \\
\hline & \multicolumn{2}{|c|}{$\mathrm{kg} \mathrm{Nha}^{-1}$} & \multicolumn{2}{|c|}{$\mathrm{Mg} \mathrm{ha}^{-1} \mathrm{yr}^{-1}$} & \multicolumn{2}{|c|}{$\mathrm{Mg} \mathrm{ha}^{-1} \mathrm{yr}^{-1}$} \\
\hline & $r_{\text {Spear }}$ & $p$ & $r_{\text {Spear }}$ & $p$ & $r_{\text {Spear }}$ & $p$ \\
\hline Total litterfall DM & 0.86 & 0.014 & & & 0.82 & 0.023 \\
\hline Total litterfall N & 0.96 & $<0.001$ & 0.89 & 0.007 & 0.57 & 0.180 \\
\hline Leaf litterfall DM & 0.54 & 0.215 & 0.82 & 0.023 & & \\
\hline Leaf litterfall N & 0.00 & 1.000 & 0.21 & 0.645 & 0.64 & 0.119 \\
\hline Total N deposition & 0.50 & 0.253 & 0.07 & 0.879 & 0.00 & 1.000 \\
\hline Tree increment DM & 0.32 & 0.482 & 0.61 & 0.148 & 0.86 & 0.014 \\
\hline Tree increment $\mathrm{N}$ & 0.43 & 0.337 & 0.79 & 0.036 & 0.93 & 0.003 \\
\hline Seepage N output & -0.50 & 0.253 & -0.71 & 0.071 & -0.43 & 0.337 \\
\hline Soil N pool change & 0.39 & 0.383 & 0.11 & 0.819 & -0.36 & 0.432 \\
\hline
\end{tabular}

and one loess substrate) (Meier et al., 2005). Leaf litterfall in mast years did not differ from that in non-mast years (Table 3), as was also observed by Müller-Haubold et al. (2015). However, a significant correlation between total and leaf litterfall was observed in this study (Table 6, Fig. 5). Similar correlations were reported by Meentemeyer et al. (1982). In mast years an additional 1.4 to $2.9 \mathrm{Mg} \mathrm{ha}^{-1}$ dry mass was returned to the soil surface. By assuming that under similar biomass production and litterfall conditions mast frequencies had doubled when compared to the historic mast frequency, the mean annual total litterfall might have increased by 0.5 to $5.11 \mathrm{Mg} \mathrm{ha}^{-1}$ and mean NPP by about $4 \%$. A fertilizing effect of $\mathrm{N}$ deposition on forest growth in Europe has been identified for many regions, most pronounced for the sites with high $\mathrm{C} / \mathrm{N}$ ratios in soils (Solberg et al., 2009; Etzold et al., 2020), suggesting that an increase in tree growth would not have been achieved under low $\mathrm{N}$ availability. The additional $\mathrm{N}$ demand for the production of total litter during mast years amounted to $32.4 \mathrm{~kg} \mathrm{Nha}^{-1}$, which translated into an annual increase of $8.7 \mathrm{~kg} \mathrm{~N}$ to $58.6 \mathrm{~kg} \mathrm{Nha}^{-1}$ compared to historic conditions. The additional $\mathrm{N}$ uptake for total litter production was even higher if the lower availability of $\mathrm{N}$ in historic times was considered. Leaf litterfall as an indicator increased the biomass and $\mathrm{N}$ increment of trees at nutrientrich sites (Table 6, Fig. 5).

\subsection{Recovery of leaf litter $N$ under high fructification frequency}

The ${ }^{15} \mathrm{~N}$ leaf litter exchange experiment on the beech forest sites indicated that about half of $\mathrm{N}$ added with the leaf litter, $17 \mathrm{~kg} \mathrm{Nha}^{-1}$, was recovered in the upper $40 \mathrm{~cm}$ of the soil during the 5.5 years (Table 5). A higher recovery of $\mathrm{N}$ was observed in a similar litter exchange experiment with labeled beech litter in three European beech stands (Zeller et al., 2001). In their study about $88 \%$ of the labeled $\mathrm{N}$ remained in the upper $30 \mathrm{~cm}$ of the soil, whereas only $2 \%$ to
$4 \%$ was incorporated in the tree biomass over 3 years. The higher recovery in the study of Zeller et al. (2001) may be attributed to a shorter duration of the experiment as immobilization of $\mathrm{N}$ exceeded the release of leaf litter $\mathrm{N}$ by mineralization during the first 2 years of the litter exchange.

The recovery of leaf litter $\mathrm{N}$ was closely related to total litterfall (Fig. 3a) but showed no relation to leaf litterfall (Fig. 3b), suggesting that fruit components as a part of total litterfall were primarily involved in the retention of leaf litter $\mathrm{N}$ (Table 6). Fruit production increased the dry mass of total litterfall by $50 \%$ compared to non-mast years (Table 4). Seeds are rich in $\mathrm{N}$ and $\mathrm{P}$, showing lower $\mathrm{C} / \mathrm{N}$ and $\mathrm{C} / \mathrm{P}$ ratios. Seed cupules contributed $51 \%$ to the dry mass of the fruit components and showed the highest $\mathrm{C} / \mathrm{N}$ and $\mathrm{C} / \mathrm{P}$ ratios of all litter fractions and may cause a high $\mathrm{N}$ demand during their decomposition. Seed cupules are woody phyllomes composed of highly recalcitrant lignocellulose tissue (Fukasawa et al., 2012). In a study on fungal succession and decomposition of Japanese beech cupule litter (Fagus crenata Blume), $77 \%$ of the original cupule weight remained at the end of a 30-month study period (Fukasawa et al., 2012). An even more delayed weight loss was recorded in England where only $6 \%$ of the cupules of European beech decomposed over a 2-year period (Carré, 1964). Most of the weight loss of seed cupules was related to the selective decomposition of holocellulose and very little to the loss of acid-nonhydrolyzable residues (Fukasawa et al., 2012). Seeds usually decompose faster than needle litter (Zackrisson et al., 1999) and most likely much faster than seed cupules, causing an $\mathrm{N}$ demand during their decomposition which may be fulfilled to some extent by the release of $\mathrm{N}$ from the decomposition of leaf litter. Even if the fruit compounds decompose simultaneously, a similar $\mathrm{C} / \mathrm{N}$ ratio of fruits (44) compared to leaf litter (43) would cause a higher $\mathrm{N}$ demand during the decomposition of fruits in mast years.

Acid soils with moder-type humus (BBR, NHB, SOB) and less acidic soils with mull-type humus (FRE, EBR, GW, 
HOM) retained almost the same amount of leaf litter N (16$17 \mathrm{~kg} \mathrm{Nha}^{-1}$ ). While the majority of leaf litter $\mathrm{N}$ was retained in the organic layer of moder-type humus soils, under more favorable conditions for decomposition most of the leaf litter $\mathrm{N}$ was transferred into the mineral soil of mull-type humus soils (Fig. 2). A high retention of leaf litter $\mathrm{N}$ in the mineral soil was observed at the base-rich GW site, because of the high abundance of saprophagous organisms (Lumbricidae and Diplopoda) (Schäfer et al., 2009; Schäfer and Schauermann, 2009). These organisms play a dominant role in the incorporation of leaf litter $\mathrm{N}$ into the mineral soil. The highest enrichment of ${ }^{15} \mathrm{~N}$-labeled $\mathrm{N}$ at the $\mathrm{GW}$ site was observed at $7-10 \mathrm{~cm}$ depth, indicating the deepest incorporation among the seven study sites. An explanation for the similar recovery of ${ }^{15} \mathrm{~N}$-labeled leaf litter in moder- and mull-type humus soils may be the short duration of the study, providing an intermediate stage of ${ }^{15} \mathrm{~N}$ incorporation into microbes and microbial products after a few years of turnover, but was probably not transformed into physically and chemically protected fractions (Parton et al., 1988) after of 5.5 years of litter exchange. Input and output flux measurements indicated that the soil at the GW site was in a quasi-steady state of formation and decomposition of humus (see Sect. 4.3).

\section{3 $\mathrm{N}$ fluxes and $\mathrm{N}$ budgets}

Positive soil $\mathrm{N}$ pool changes $\left(\Delta \mathrm{N}_{\mathrm{S}}\right.$, Eq. 1$)$ indicated a retention of $\mathrm{N}$ in the soil at all sites except the BBR site where a slightly negative budget may point to humus degradation (Ulrich, 1992) (Table 5). Soil N change was not related to the total litterfall (Table 6), indicating that mast was not the prevailing factor controlling the retention of deposited $\mathrm{N}$ in soils. Our study suggests that soil $\mathrm{P}$ was involved in processes regulating $\mathrm{N}$ retention in soils. Soil $\mathrm{N}$ retention rate was associated with high $\mathrm{N} / \mathrm{P}$ ratios in the organic layer and high $\mathrm{C} / \mathrm{P}$ ratios in the mineral soil (Figs. 4,5 ). High $\mathrm{N}$ depositions may have induced an imbalance of $\mathrm{P}$ and $\mathrm{N}$ nutrition. Several studies indicated that $\mathrm{N}$ deposition increased the $\mathrm{N}$ retention rate in soils until the 1990s (Hyvönen et al., 2008; De Vries et al., 2006; Brumme and Khanna, 2008; Meiwes et al., 2009). Talkner et al. (2015) observed that foliar P content in 79 ICP Forests Level II European beech plots in Europe decreased from 1991 to 2010, indicating a reduced $P$ availability with increasing $\mathrm{N}$ enrichment and increasing soil acidification. Critical N/P ratios for litter decomposition are often suggested in the literature (Aerts, 1997; Smith, 2002; Güsewell and Freeman, 2005), implying that the decomposition of litter with high N/P ratios is limited by insufficient $\mathrm{P}$ availability. Moreover, the bioavailability of inorganic $\mathrm{P}$ can be severely limited in acid soils by aluminum, which may restrict the functionality of the microbial community (Goldberg et al., 1997; DeForest and Scott, 2010).

The seven sites studied here are a part of 53 Level II plots in Germany of which half $(n=27)$ retained $\mathrm{N}$ in the soil calculated by input-output balances (Brumme and Khanna,
2008). $\mathrm{N}$ retention increased with the level of total $\mathrm{N}$ and sulfur deposition and the thickness of the organic layer at sites with moder-type humus $(n=21)$, indicating the role of organic layers for the retention of $\mathrm{N}$ input in acid soils under high atmospheric load. In several studies simulated acid rain and ammonium additions affected soil microbial activity and thus the $\mathrm{C}$ and $\mathrm{N}$ cycling in ecosystems in the short term (Persson and Wirén, 1993; Berg and Matzner, 1997; Janssens et al., 2010). In the long term, atmospheric deposition may lead to the formation of a decomposer refuge by soil acidification (Ulrich, 1992) and high-N leaf litter, which decomposes at a lower rate than litter with low $\mathrm{N}$ in the later stages of decomposition, increasing the accumulation of $\mathrm{C}$ and $\mathrm{N}$ in the organic layer (Berg et al., 1995). Field measurements confirmed the high potential for soil $\mathrm{N}$ retention in an acid soil with moder-type humus at the SOB site but not in the less acidic soil with mull-type humus at the GW site (Meiwes et al., 2009; Brumme and Khanna, 2009). Almost all of the deposited $\mathrm{N}$ in excess for plant increment or gaseous outputs was retained in the organic layer of the SOB site as indicated by the soil inventories for the period of 1966 to 2001 (Meiwes et al., 2009). The annual increase in the organic layer equalled $21 \mathrm{~kg} \mathrm{Nha}^{-1}$ and $347 \mathrm{~kg} \mathrm{Cha}^{-1}$ and was confirmed by input and output measurements between 1981 and 2002 (Brumme and Khanna, 2009). In contrast, at the less acidic GW site with mull-type humus, most of the $\mathrm{N}$ was either used for tree $\mathrm{N}$ increment or leached with seepage water with little retention in the soil. Hence, the SOB site was classified to be in the state of humus accumulation (accumulation type) and the GW site in a (quasi-) steady state of formation and decomposition of humus (Brumme and Khanna, 2008). Recent observations at two forest sites proved the direct effect of $\mathrm{S}$ deposition as the main driver for $\mathrm{N}$ retention in forest soils. After emission control at the end of the 1990s and reduced atmospheric deposition, the $\mathrm{C}$ and $\mathrm{N}$ pools in the organic layer declined at the SOB site from $1.86 \mathrm{Mg} \mathrm{Nha}^{-1}$ in 1993 to $0.99 \mathrm{Mg} \mathrm{N} \mathrm{ha}^{-1}$ in 2010 (Förster et al., 2017) as well as at a spruce stand in the Czech Republic (Oulehle et al., 2011), indicating a predominant effect of atmospheric deposition on microbial activity and $\mathrm{N}$ retention.

Studies with ${ }^{15} \mathrm{~N}$-labeled $\mathrm{N}$ deposition provide a useful insight into the initial retention processes of $\mathrm{N}$ deposition in the forest ecosystems. Irrigation studies with ${ }^{15} \mathrm{~N}$-labeled ammonium on undisturbed soil cores $(30 \mathrm{~cm}$ length) from the SOB site in the field indicated a N retention of $20 \%$ in the organic layer and $26 \%$ in the mineral soil over a period of 12 months (Brumme et al., 2009a). Irrigation studies of undisturbed cores from different soil depths of the SOB soil showed a $\mathrm{N}$ retention of $54 \%$ in the organic layer and of $34 \%$ in each of the mineral soil layers $(0-10 \mathrm{~cm}, 10-20 \mathrm{~cm}$ depth) after a 2-month irrigation with ${ }^{15} \mathrm{NH}_{4}$ at $8{ }^{\circ} \mathrm{C}$ in the laboratory. Low nitrification rates (heterotrophic) at the SOB site (Bauhus et al., 1996; Brumme et al., 2009b) result in the adsorption of ${ }^{15} \mathrm{~N}$-labeled ammonium and contributed $3 \%$ to the $\mathrm{N}$ retention of $54 \%$ in the organic layer, $24 \%$ of $34 \%$ in 
$0-10 \mathrm{~cm}$, and $30 \%$ of $34 \%$ in $10-20 \mathrm{~cm}$ soil depth. A high adsorption capacity for ammonium extended the residence time and the potential for transformation processes due to microbial immobilization and plant uptake in acidic soils and may have increased the transformation of deposited ammonium in organic compounds. Nitrate was only marginally retained in the soil layers of the SOB site $(<3 \%)$ as shown by a comparable study with ${ }^{15} \mathrm{~N}$-labeled nitrate (Brumme et al., 2009a). The less acidic GW site had a similar retention of $45 \%$ of ${ }^{15} \mathrm{~N}$-labeled ammonium in $30 \mathrm{~cm}$ soil cores compared to the acidic SOB site ( $46 \%$ recovery). However, the adsorption of ammonium at the GW site was negligible due to high autotrophic nitrification. Most of the ${ }^{15} \mathrm{~N}$ retained in the GW cores was transformed to organic compounds in the mineral soil. The high $\mathrm{N}$ retention in the mineral soil of the less acidic GW site was evident from the high microbial biomass, which was 2 times higher at the GW compared to the SOB site, especially in the mineral soil, where it was 5 times higher (Brumme et al., 2009c). Ammonium retention was closely related to the microbial biomass at the SOB and GW soils, indicating its dominant control on ammonium retention in forest soils in the short term. Within the NITREX project, where the fate of doubled ${ }^{15} \mathrm{~N}$-labeled ${ }^{15} \mathrm{NH}_{4}^{15} \mathrm{NO}_{3}$ in throughfall was studied over a 12-month period, $\mathrm{N}$ retention was twice as high in the organic layer as in the mineral soil of a podzolic soil in Denmark (26\% versus $12 \%$ recovery; Tietema et al., 1998). The uptake of ${ }^{15} \mathrm{~N}$ by ground vegetation and trees amounted to $45 \%$ of the applied ${ }^{15} \mathrm{~N}$, showing that a large part of the deposited $\mathrm{N}$ was introduced into the internal $\mathrm{N}$ cycle. Most of the $\mathrm{N}$ usually returns back to the soil with litterfall in the following year and may be retained in the soil by mast products, as was observed in the ${ }^{15} \mathrm{~N}$-labeled leaf litter exchange experiment. Thus, the initial microbial retention of $\mathrm{N}$ is one pathway into labile organic $\mathrm{N}$ compounds while the repeated plant uptake and litterfall of $\mathrm{N}$ are probably the common transformation processes producing more stable $\mathrm{N}$ compounds in soils.

Tree $\mathrm{N}$ increment increased with decreasing $\mathrm{C} / \mathrm{N}$ ratio in the mineral soil (Fig. 5) and retained on average twice as much $\mathrm{N}$ compared to changes in the $\mathrm{N}$ pool of soils (Table 5). Sites with a low $\mathrm{C} / \mathrm{N}$ ratio in the mineral soil are often characterized by high soil biological activity increasing $\mathrm{N}$ content in relation to C (Swift et al., 1979). The base-rich GW site for example contained an almost 2 times higher microbial biomass and a higher abundance of earthworms than the acidic SOB site (Brumme et al., 2009a; Schäfer et al., 2009) and retained $+60 \% \mathrm{~N}$ by tree increment and $-71 \% \mathrm{~N}$ by soil $\mathrm{N}$ change compared to the SOB site. N budgets of 53 ICP Level II plots in Germany confirmed the dominant role of the soil chemical status for the retention of $\mathrm{N}$ in soils and trees (Brumme and Khanna, 2008). It was found that $\mathrm{N}$ retention by trees decreased and that of soils increased with a decrease in the availability of base cations. $\mathrm{N}$ retention processes by trees and soils in conjunction with total $\mathrm{N}$ deposition determined the seepage output of $\mathrm{N}$ at our study sites, whereas gaseous $\mathrm{N}$ losses were of minor importance. A positive relationship between seepage $\mathrm{N}$ losses and contents of $\mathrm{N}, \mathrm{C}, \mathrm{P}$, and clay in the mineral soil (Fig. 5) suggests that sites with a high $\mathrm{N}$ pool in the mineral soil retained less $\mathrm{N}$ in soil and plants than sites with a low $\mathrm{N}$ pool. High mineral soil $\mathrm{N}$ pools are typically found at sites that are close to a (quasi-) steady state with high elasticity against environmental changes like deposited acidity, which is buffered by silicates or carbonates. These sites usually exhibit a high biological activity in the mineral soil, forming a mull-type humus (Ulrich, 1992; Brumme and Khanna, 2008). At such sites most of the $\mathrm{N}$ is retained through tree uptake, and any additional $\mathrm{N}$ from deposition is leached from the soil with the seepage water flux.

\section{Conclusions}

The role of mast in the nutrient cycling processes in beech forests has so far received little attention because of the irregular nature of the mast production. When comparing historic data with results from litterfall observations across Europe since the 1990s, an increase in fructification frequency is obvious. The higher mast frequency has increased the amount of $\mathrm{C}$ and $\mathrm{N}$ additions to the soil, which increased the internal cycling between plants and soil including decomposition. Litterfall fluxes were accompanied by a change in the litter quality involving high amounts of easily decomposable seeds on the one hand and less decomposable (recalcitrant) seed cupules with very high $\mathrm{C} / \mathrm{N}$ and $\mathrm{C} / \mathrm{P}$ ratios on the other. The application of ${ }^{15} \mathrm{~N}$-labeled leaf litter indicated that these changes may be responsible for increased sequestration of leaf litter $\mathrm{N}$ during decomposition of seed cupules in stands with a high mast frequency. Thus, mast affected the retention of $\mathrm{N}$ after plant uptake and leaf litterfall but did not affect the retention of deposited $\mathrm{N}$ calculated by input and output fluxes. The retention of $\mathrm{N}$ in the soil is controlled by atmospheric depositions and soil acidity as indicated by input and output flux measurements. Atmospheric depositions affected $\mathrm{N}$ retention by reducing decomposition processes but also by changing the environment of decomposers through soil acidity and nutrient imbalances. The N/P ratio and soil acidity have increased, reducing the $\mathrm{P}$ availability and litter decomposition processes. In our study $\mathrm{N}$ retention in acidic soils increased with the thickness of the organic layer and the $\mathrm{N}$ and $\mathrm{S}$ deposition, while in less acidic soils with higher nutrient turnover and low $\mathrm{C} / \mathrm{N}$ ratios in the mineral soil layers, elevated plant uptake dominates the $\mathrm{N}$ retention. Such sites are characterized by a low soil $\mathrm{N}$ retention.

Data availability. The majority of data used for regression and correlation analysis are presented here in the tables. The raw and not yet aggregated data and other datasets are available from the authors upon request. 
Author contributions. RB, BA, and HM designed and conceptualized the study. All authors contributed to preparation, preprocessing, and aggregation of measurement data (deposition, litterfall, seepage flux, uptake, tree growth, etc.) of the different federal states included. RB performed experimental setup, sampling, and interpretation of the ${ }^{15} \mathrm{~N}$ data. All authors contributed to writing, reviewing, and editing the manuscript as well as commenting on it.

Competing interests. The authors declare that they have no conflict of interest.

Disclaimer. The field studies did not involve endangered or protected species, and no specific permission was required for these locations/activities.

Publisher's note: Copernicus Publications remains neutral with regard to jurisdictional claims in published maps and institutional affiliations.

Acknowledgements. We thank our colleagues from the Northwest German Forest Research Institute, from the Bavarian State Institute of Forestry and from the Forschungsanstalt für Waldökologie und Forstwirtschaft for their contributions to field sampling and maintenance, for laboratory analyses, and for data management. In particular, we thank Heike Fortmann, Ulrike Talkner, Hans-Peter Dietrich, Stephan Raspe, and Julius Schuck for data acquisition and the KOSI laboratory (Centre for Stable Isotope Research and Analysis, Göttingen) for the analysis of stable ${ }^{15} \mathrm{~N}$ in plant and soil samples.

Data collection at study sites in Lower Saxony have been funded since 1992 by the State of Lower Saxony through the Permanent Soil Monitoring Programme (BDF). The constructive comments by the two anonymous reviewers, which helped to improve the manuscript significantly, are gratefully acknowledged.

Financial support. Partial funding of data collection was provided by the European Union under Council Regulation (EEC) 3528/86 on the "Protection of Forests against Atmospheric Pollution" and the Regulation (EC) 2152/2003 concerning monitoring of forests and environmental interactions in the community (Forest Focus) and by the project LIFE 07 ENV/D/000218 "Further Development and Implementation of an EU-level Forest monitoring System (FutMon)".

Review statement. This paper was edited by Frank Hagedorn and reviewed by two anonymous referees.

\section{References}

Aerts, R.: Climate, leaf litter chemistry and leaf litter decomposition in terrestrial ecosystems: a triangular relationship, Oikos, 79, 439-449, https://doi.org/10.2307/3546886, 1997.

Ahrends, B., Schmidt-Walter, P., Fleck, S., Köhler, M., and Weis, W.: Wasserhaushaltssimulationen und Klimadaten, Freibg. Forstl. Forsch., 101, 74-94, 2018.

Ahrends, B., Schmitz, A., Prescher, A.-K., Wehberg, J., Geupel, M., Andreae, H., and Meesenburg, H.: Comparison of Methods for the Estimation of Total Inorganic Nitrogen Deposition to Forests in Germany, Front. For. Glob. Change, 3, https://doi.org/10.3389/ffgc.2020.00103, 2020.

Bauhus, J., Meyer, A. C., and Brumme, R.: Effect of the inhibitors nitrapyrin and sodium chlorate on nitrification and $\mathrm{N}_{2} \mathrm{O}$ formation in an acid forest soil, Biol. Fert. Soils, 22, 318-325, https://doi.org/10.1007/BF00334576, 1996.

Baumgarten, M., Weis, W., Kühn, A., May, K., and Matyssek, R.: Forest transpiration - targeted through xylem sap flux assessment versus hydrological modeling, Eur. J. For. Res., 133, 677-690, https://doi.org/10.1007/s10342-014-0796-4, 2014.

Berg, B. and Matzner, E.: Effect of $\mathrm{N}$ deposition on decomposition of plant litter and soil organic matter in forest systems, Environ. Res., 5, 1-25, https://doi.org/10.1139/a96-017, 1997.

Berg, B. and McClaugherty, C.: Plant litter: decomposition, humus formation, carbon sequestration, 4th Edn., Berlin Heidelberg, Springer, https://doi.org/10.1007/978-3-030-59631-6, 2020.

Berg, B., McClaugherty, C., Santo, A. V. d., Johansson, M.B., and Ekbohm, G.: Decomposition of litter and soil organic matter - Can we distinguish a mechanism for soil organic matter buildup?, Scand. J. Forest Res., 10, 108-119, https://doi.org/10.1080/02827589509382874, 1995.

Bezdeckova, L. and Matejka, K.: The quality and the depth of dormancy of beechnuts in individual stand groups with varying climatic conditions within a single unit of approval, J. For. Sci., 61, 382-392, https://doi.org/10.17221/44/2015-JFS, 2015.

Bogdziewicz, M., Crone, E. E., Steele, M. A., and Zwolak, R.: Effects of nitrogen deposition on reproduction in a masting tree: benefits of higher seed production are trumped by negative biotic interactions, J. Ecol., 105, 310-320, https://doi.org/10.1111/1365-2745.12673, 2017.

Braun, S., Thomas, V. F. D., Quiring, R., and Flückiger, W.: Does nitrogen deposition increase forest production? The role of phosphorus, Environ. Pollut., 158, 2043-2052, https://doi.org/10.1016/j.envpol.2009.11.030, 2010.

Brumme, R. and Borken, W.: $\mathrm{N}_{2} \mathrm{O}$ Emission from Temperate Beech Forest Soils, in: Functioning and Management of European Beech Ecosystems, edited by: Brumme, R. and Khanna, P., Ecol. Stud., Vol. 208, Springer, Berlin, Heidelberg, 353-367, https://doi.org/10.1007/b82392_19, 2009.

Brumme, R. and Khanna, P. K.: Ecological and site historical aspects of $\mathrm{N}$ dynamics and current $\mathrm{N}$ status in temperate forests, Glob. Change Biol., 14, 125-141, https://doi.org/10.1111/j.13652486.2007.01460.x, 2008.

Brumme, R. and Khanna, P. K.: Stand, soil and nutrient factors determining the functioning and management of beech forest ecosystems: A synopsis, in: Functioning and Management of European Beech Ecosystems, edited by: Brumme, R., and Khanna, P., Ecol. Stud., Vol. 208, Springer, Berlin, Heidelberg, 459-490, https://doi.org/10.1007/b82392_24, 2009. 
Brumme, R., Wang, C. P., Priess, J., Raubuch, M., and Steinmetz, G.: Fate, Transport, and Retention of Applied ${ }^{15} \mathrm{~N}$ Labelled Nitrogen in Forest Soils, in: Functioning and Management of European Beech Ecosystems, edited by: Brumme, R. and Khanna, P., Ecol. Stud., Vol. 208, Springer, Berlin, Heidelberg, 253-265, https://doi.org/10.1007/b82392_7, 2009a.

Brumme, R., Priess, J., Wang, C. P., Raubuch, M., Steinmetz, G., and Meyer, H.: Nitrogen and Carbon Transformation, in: Functioning and Management of European Beech Ecosystems, edited by: Brumme, R., and Khanna, P., Ecol. Stud., Vol. 208, Springer, Berlin, Heidelberg, 231-252, https://doi.org/10.1007/b82392_7 2009b.

Brumme, R., Raubuch, M., Priess, J., Wang, C. P., and Anderson, T.: Microbial Biomass, in: Functioning and Management of European Beech Ecosystems, edited by: Brumme, R., and Khanna, P., Ecol. Stud., Vol. 208, Springer, Berlin, Heidelberg, 87-92, https://doi.org/10.1007/b82392_7, 2009c.

Burschel, P.: Untersuchungen in Buchenmastjahren, Forstw. Cbl., 85, 204-219, 1966.

Carré, C. G.: Fungus decomposition of beech cupules, Trans. Brit. Mycol. Soc., 47, 437-444, https://doi.org/10.1016/S00071536(64)80015-2, 1964.

Clarke, N., Zlindra, D., Ulrich, E., Mosello, R., Derome, J., Derome, K., König, N., Lövblad, G., Draaijers, G., Hansen, K., Thimonier, A., and Waldner, P.: Part XIV: Sampling and Analysis of Deposition, in: UNECE ICP Forests Programme Co-ordinating Centre: Manual on methods and criteria for harmonized sampling, assessment, monitoring and analysis of the effects of air pollution on forests, Thünen Institute of Forest Ecosystems, Eberswalde, Germany, 44 pp., available at: http://icp-forests.net/page/icp-forests-manual (last access: 19 June 2021), 2016.

Cools, N. and De Vos, B.: Availability and evaluation of European forest soil monitoring data in the study on the effects of air pollution on forests, iForest - Biogeosciences and Forestry, 4, 205211, https://doi.org/10.3832/ifor0588-004, 2011.

Cools, N. and De Vos, B.: Part X: Sampling and Analysis of Soil, in: UNECE ICP Forests Programme Co-ordinating Centre: Manual on methods and criteria for harmonized sampling, assessment, monitoring and analysis of the effects of air pollution on forests. Thünen Institute of Forest Ecosystems, Eberswalde, Germany, 29 pp + Annex, available at: http://icp-forests.net/page/ icp-forests-manual (last access: 19 June 2021), 2016.

DeForest, J. L. and Scott, L. G.: Available organic soil phosphorus has an important influence on microbial community composition, Soil Sci. Soc. Am. J., 74, 2059-2066, https://doi.org/10.2136/sssaj2009.0426, 2010.

De Vries, W., Vel, E., Reinds, G. J., Dellstra, H., Klap, J. M., Leeters, E. E. J. M., Hendricks, C. M. A., Kerkvoorden, M., Landmann, G., Herkendell, J., Haussmann, T., and Erisman, J. $\mathrm{W}$.: Intensive monitoring of forest ecosystems in Europe: 1. Objectives, set-up and evaluation strategy, Forest Ecol. Manag., 174, 77-95, https://doi.org/10.1016/S0378-1127(02)00029-4, 2003a.

De Vries, W., Kros, J., Oenema, O., and de Klein, J.: Uncertainties in the fate of nitrogen II: A quantitative assessment of the uncertainties in major nitrogen fluxes in the Netherlands, Nutr. Cycl. Agroecosys., 66, 71-102, https://doi.org/10.1023/A:1023354109910, 2003b.
De Vries, W., Reinds, G. J., Gundersen, P., and Sterba, H.: The impact of nitrogen deposition on carbon sequestration in European forests and forest soils, Glob. Change Biol., 12, 1151-1173, https://doi.org/10.1111/j.1365-2486.2006.01151.x, 2006.

De Vries, W., Dobbertin, M. H., Solberg, S., Van Dobben, H. F., and Schaub, M.: Impacts of acid deposition, ozone exposure and weather conditions on forest ecosystems in Europe: an overview, Plant Soil, 380, 1-45, https://doi.org/10.1007/s11104-014-20562, 2014.

Dobbertin, M. and Neumann, M.: Part V: Tree Growth, in: UNECE ICP Forests Programme Co-ordinating Centre: Manual on methods and criteria for harmonized sampling, assessment, monitoring and analysis of the effects of air pollution on forests, Thünen Institute of Forest Ecosystems, Eberswalde, Germany, 17 pp., available at: http://icp-forests.net/page/icp-forests-manual (last access: 19 June 2021), 2016.

Eickenscheidt, N. and Brumme, R.: Regulation of $\mathrm{N}_{2} \mathrm{O}$ and $\mathrm{NO}_{x}$ emission patterns in six acid temperate beech forest soils by soil gas diffusivity, $\mathrm{N}$ turnover, and atmospheric $\mathrm{NO}_{x}$ concentrations, Plant Soil, 369, 515-529, https://doi.org/10.1007/s11104013-1602-7, 2013.

Engardt, M., Simpson, D., Schwikowski, M., and Granat, L.: Deposition of sulphur and nitrogen in Europe 1900-2050. Model calculations and comparison to historical observations, Tellus B, 69, 1328945, https://doi.org/10.1080/16000889.2017.1328945, 2017.

Etzold, S., Ferretti, M., Reinds, G. J., Solberg, S., Gessler, A., Waldner, P., Schaub, M., Simpson, D., Benham, S., Hansen, K., Ingerslev, M., Jonard, M., Karlsson, P. E., Lindroos, A. J., Marchetto, A., Manninger, M., Meesenburg, H., Merilä, P., Nöjd, P., Rautio, P., Sanders, T. G., Seidling, W., Skudnik, M., Thimonier, A., Verstraeten, A., Vesterdal, L., Vejpustkova, M., and De Vries, W.: Nitrogen deposition is the most important environment driver of growth of pure, even-aged and managed European forests, Forest Ecol. Manag., 458, 117762, https://doi.org/10.1016/j.foreco.2019.117762, 2020.

Fleck, S., Cools, N., De Vos, B., Meesenburg, H., and Fischer, R.: The Level II aggregated forest soil condition database links soil physicochemical und hydraulic properties with long-term observations of forest condition in Europe, Ann. For. Sci., 73, 945957, https://doi.org/10.1007/s13595-016-0571-4, 2016.

Fleck, S., Eickenscheidt, N., Ahrends, B., Evers, J., Grüneberg, E., Ziche, D., Höhle, J., Schmitz, A., Weis, W., SchmidtWalter, P., Andreae, H., and Wellbrock, N.: Nitrogen Status and Dynamics in German Forest Soils, Ecological Studies (Analysis and Synthesis), Springer Verlag Berlin, 123-166, https://doi.org/10.1007/978-3-030-15734-0_5, 2019.

Förster, A., Becker, T., Gerlach, A., Meesenburg, H., and Leuschner, C.: Long-term change in understory plant communities of conventionally managed temperate deciduous forests: effects of nitrogen deposition and forest management, J. Veg. Sci., 28, 747-761, https://doi.org/10.1111/jvs.12537, 2017.

Fukasawa, Y., Tateno, O., Hagiwara, Y., Hirose, D., and Osono, T.: Fungal succession and decomposition of beech cupule litter, Ecol. Res., 27, 735-743, https://doi.org/10.1007/s11284-0120947-3, 2012.

Galloway, J. N., Townsend, A. R., Erisman, J. W., Bekunda, M., Cai, Z., Freney, J. R., Martinelli, L. A., Seitzinger, S. P., and Sutton, M. A.: Transformation of the Nitrogen Cycle: Recent 
Trends, Questions, and Potential Solutions, Science, 320, 889892, https://doi.org/10.1126/science.1136674, 2008.

Goldberg, S., Davis, J., and Hem, J.: The surface chemistry of aluminum oxides and hydroxides, in: The Environmental Chemistry of Aluminum, edited by: Sposito, G., Lewis Publishers, 2nd Edn., Boca Raton, New York, London, Tokyo, 271-331, 1997.

Güsewell, S. and Freeman, C.: Nutrient limitation and enzyme activities during litter decomposition of nine wetland species in relation to litter $\mathrm{N}: \mathrm{P}$ ratios, Funct. Ecol., 19, 582-593, https://doi.org/10.1111/j.1365-2435.2005.01002.x, 2005.

Hallbäcken, L. and Tamm, C. O.: Changes in soil acidity from 1927 to $1982-1984$ in a forest area of South-West Sweden, Scand. J. For. Res., 1, 219-232, https://doi.org/10.1080/02827588609382413, 1986.

Hammel, K. and Kennel, M.: Charakterisierung und Analyse der Wasserverfügbarkeit und des Wasserhaushalts von Waldstandorten in Bayern mit dem Simulationsmodell BROOK90, Forstl. Forsch.ber. Münch., Heinrich Frank, München, 148 pp., 2001.

Hase, W.: Die Buchenmast in Schleswig-Holstein und ihre Abhängigkeit von der Witterung, Dt. Wetterdienst, Offenbach, Main, 52 pp., 1964.

Hyvönen, R., Persson, T., Andersson, S., Olsson, B., Ågren, G. I., and Linder, S.: Impact of long-term nitrogen addition on carbon stocks in trees and soils in northern Europe, Biogeochemistry, 89, 121-137, https://doi.org/10.1007/s10533-007-9121-3, 2008.

Jacobsen, C., Rademacher, P., Meesenburg, H., and Meiwes, K. J.: Gehalte chemischer Elemente in Baumkompartimenten - Literaturstudie und Datensammlung, Ber. Forsch.zent. Waldökosyst., Reihe B, 69, 81 pp., 2003.

Jankiewicz, P., Neumann, J., Duijnisveld, W., Wessolek, G., Wycisk, P., and Hennings, V.: Abflusshöhe - Sickerwasserrate Grundwasserneubildung - Drei Themen im Hydrologischen Atlas von Deutschland, Hydrol. Wasserbewirts., 49, 2-13, 2005.

Janssens, I. A., Dieleman, W., Luyssaert, S., Subke, J. A., Reichstein, M., Ceulemans, R., Ciais, P., Dolman, A. J., Grace, J., Matteucci, G., Papale, D., Piao, S. L., Schulze, E. D., Tang, J., and Law, B. E.: Reduction of forest soil respiration in response to nitrogen deposition, Nat. Geosci., 3, 315-322, https://doi.org/10.1038/ngeo844, 2010.

Jansson, P. E. and Karlberg, L.: Coupled heat and mass transfer model for soil-plant atmosphere system, Dept. civil and environmental engineering, Royal Institute of Technology, Stockholm, 445 pp., 2004.

Kaliniewicz, Z., Tylek, P., Anders, A., Markowski, P., Rawa, T., and Andros, K.: Correlations between basic physical parameters of nuts and the weight of common beech (Fagus sylvatica L.) seeds, Technical Sciences, 18, 5-14, 2015.

Karl, S., Block, J., Schüler, G., Schultze, B., and Scherzer, J.: Wasserhaushaltsuntersuchungen im Rahmen des Forstlichen Umweltmonitorings und bei waldbaulichen Versuchen in Rheinland-Pfalz, Mitteilungen aus der Forschungsanstalt für Waldökologie und Forstwirtschaft Rheinland-Pfalz, 71, 1-289, 2012

Kelly, D., Geldenhuis, A., James, A., Penelope Holland, E., Plank, M. J., Brockie, R. E., Cowan, P. E., Harper, G. A., Lee, W. G., Maitland, M. J., Mark, A. F., Mills, J. A., Wilson, P. R., and Byrom, A. E.: Of mast and mean: differential-temperature cue makes mast seeding insensitive to climate change, Ecol. Lett., 16, 90-98, https://doi.org/10.1111/ele.12020, 2013.
Khanna, P. K., Fortmann, H., Meesenburg, H., Eichhorn, J., and Meiwes, K. J.: Biomass and element content of foliage and aboveground litterfall on the three long-term experimental beech sites: Dynamic and significance, in: Functioning and Management of European Beech Ecosystems, edited by: Brumme, R. and Khanna, P., Ecol. Stud., Vol. 208, Springer, Berlin, Heidelberg, 183-205, https://doi.org/10.1007/b82392_12, 2009.

König, N., Forstmann, H., and Lüter, K. L.: Probenvorbereitungs-, Untersuchungs- und Elementbestimmungs-Methoden des Umweltanalytik-Labors der Niedersächsischen Forstlichen Versuchsanstalt, Ber. Forsch.zent. Waldökosyst., Reihe B, 75, 364 pp., 2009.

LeBauer, D. S. and Treseder, K. K.: Nitrogen limitation of net primary productivity in terrestrial ecosystems is globally distributed, Ecology, 89, 371-379, https://doi.org/10.1890/062057.1, 2008.

Lebourgeois, F., Delpierre, N., Dufrêne, E., Cecchini, S., Macé, S., Croisé, L., and Nicolas, M.: Assessing the roles of temperature, carbon inputs and airborne pollen as drivers of fructification in European temperate deciduous forests, Eur. J. For. Res., 137, 349-365, https://doi.org/10.1007/s10342-018-1108-1, 2018.

Meesenburg, H., Eichhorn, J., and Meiwes, K. J.: Atmospheric Deposition and Canopy Interactions, in: Functioning and Management of European Beech Ecosystems, edited by: Brumme, R. and Khanna, P., Ecol. Stud., Vol. 208, Springer, Berlin, Heidelberg, 265-302, https://doi.org/10.1007/b82392_16, 2009.

Meentemeyer, V., Box, E. O., and Thompson, R.: Worlds patterns and amounts of terrestrial plant litter production, BioScience, 32, 125-128, https://doi.org/10.2307/1308565, 1982.

Meesenburg, H., Ahrends, B., Fleck, S., Wagner, M., Fortmann, H., Scheler, B., Klinck, U., Dammann, I., Eichhorn, J., Mindrup, M., and Meiwes, K. J.: Long-term changes of ecosystem services at Solling, Germany: Recovery from acidification, but increasing nitrogen saturation?, Ecol. Indic., 65, 103-112, https://doi.org/10.1016/j.ecolind.2015.12.013, 2016.

Meier, I. C., Leuschner, C., and Hertel, D.: Nutrient return with leaf litter fall in Fagus sylvatica forests across a soil fertility gradient, Plant Ecol., 177, 99-112, https://doi.org/10.1007/s11258005-2221-z, 2005.

Meiwes, K. J., Meesenburg, H., Eichhorn, J., Jacobsen, C., and Khanna, P. K.: Changes in $\mathrm{C}$ and $\mathrm{N}$ content of soils under beech forests over a period of 35 years, in: Functioning and Management of European Beech Ecosystems, edited by: Brumme, R. and Khanna, P., Ecol. Stud., Vol. 208, Springer, Berlin, Heidelberg, https://doi.org/10.1007/b82392_5, 49-63, 2009.

Müller-Haubold, H., Hertel, D., and Leuschner, C.: Climatic Drivers of Mast Fruiting in European Beech and Resulting $\mathrm{C}$ and $\mathrm{N}$ Allocation Shifts, Ecosystems, 18, 1083-1100, https://doi.org/10.1007/s10021-015-9885-6, 2015.

Mund, M., Herbst, M., Knohl, A., Matthäus, B., Schumacher, J., Schall, P., Siebicke, L., Tamrakar, R., and Ammer, C.: It is not just a 'trade-off': indications for sink- and source-limitation to vegetative and regenerative growth in an old-growth beech forest, New Phytol., 226, 111-125, https://doi.org/10.1111/nph.16408, 2020.

Neary, D. G., Ice, G. G., and Jackson, C. R.: Linkages between forest soils and water quality and quantity, Forest Ecol. Manag., 258, 2269-228, https://doi.org/10.1016/j.foreco.2009.05.027, 2009 . 
Neumann, M., Ukonmaanaho, L., Johnson, J., Benham, S., Vesterdal, L., Novotný, R., Verstraeten, A., Lundin, L., Thimonier, A., Michopoulos, P., and Hasenauer, H.: Quantifying carbon and nutrient input from litterfall in European forests using field observations and modeling, Global Biogeochem. Cy., 32, 784-798, https://doi.org/10.1029/2017GB005825, 2018.

Nieminen, T. M., De Vos, B., Cools, N., König, N., Fischer, R., Iost, S., Meesenburg, H., Nicolas, M., O’Dea, P., Cecchini, G., Ferretti, M., De La Cruz, A., Derome, K., Lindroos, A. J., and Graf Pannatier, E.: Part XI: Soil Solution Collection and Analysis, in: UNECE ICP Forests Programme Co-ordinating Centre: Manual on methods and criteria for harmonized sampling, assessment, monitoring and analysis of the effects of air pollution on forests. Thünen Institute of Forest Ecosystems, Eberswalde, Germany, 20 pp. + Annex, available at: http://icp-forests.net/ page/icp-forests-manual (last access: 19 June 2021), 2016.

Nielsen, P. C. and De Muckadeli, M. S.: Flower observations and controlled pollinations in Fagus, Silvae Genetica 3, 6-17, 1954

Nussbaumer, A., Waldner, P., Etzold, S., Gessler, A., Benham, S., Thomsen, I. M., Jørgensen, B. B., Timmermann, V., Verstraeten, A., Sioen, G., Rautio, P., Ukonmaanaho, L., Skudnik, M., Apuhtin, V., Braun, S., and Wauer, A.: Patterns of mast fruiting of common beech, sessile and common oak, Norway spruce and Scots pine in Central and Northern Europe, Forest Ecol. Manag., 363, 237-251, https://doi.org/10.1016/j.foreco.2015.12.033, 2016.

Nussbaumer, A., Waldner, P., Apuhtin, V., Aytar, F., Benham, S., Bussotti, F., Eichhorn, J., Eickenscheidt, N., Fabianek, P., Falkenried, L., Leca, S., Lindgren, M., Manzano Serrano, M. J., Neagu, S., Nevalainen, S., Pajtik, J., Potočić, N., Rautio, P., Sioen, G., Stakenas, V., Tasdemir, C., Thomsen, I. M., Timmermann, V., Ukonmaanaho, L., Verstraeten, A., Wulff, S., and Gessler, A.: Impact of weather cues and resource dynamics on mast occurrence in the main forest tree species in Europe, Forest Ecol. Manag., 429, 336-350, https://doi.org/10.1016/j.foreco.2018.07.011, 2018.

Oulehle, F., Evans, C. D., Hofmeister, J., Krejci, R., Tahovska, K., Persson, T., Cudlin, P., and Hruska, J.: Major changes in forest carbon and nitrogen cycling caused by declining sulphur deposition, Glob. Change Biol., 17, 3115-3129, https://doi.org/10.1111/j.1365-2486.2011.02468.x, 2011.

Övergaard, R., Gemmel, P., and Karlsson, M.: Effects of weather conditions on mast year frequency in beech (Fagus sylvatica L.) in Sweden, Forestry, 80, 555-565, https://doi.org/10.1093/forestry/cpm020, 2007.

Paar, U., Guckland, A., Dammann, I., Albrecht, A., and Eichhorn, J.: Häufigkeit und Intensität der Fruktifikation der Buche, AFZ/Der Wald, 6, 26-29, 2011.

Panferov, O., Doering, C., Rauch, E., Sogachev, A., and Ahrends, B.: Feedbacks of windthrow for Norway spruce and Scots pine stands under changing climate, Environ. Res. Lett., 4, 045019, https://doi.org/10.1088/1748-9326/4/4/045019, 2009.

Parton, W. J., Stewart, J. W. B., and Cole, C. V.: Dynamics of C, $\mathrm{N}, \mathrm{P}$ and $\mathrm{S}$ in grassland soils: a model, Biogeochemistry, 5, 109131, https://doi.org/10.1007/BF02180320, 1988.

Persson, T. and Wirén, A.: Effects of experimental acidification on $\mathrm{C}$ and $\mathrm{N}$ mineralization in forest soils, Agr. Ecosyst. Environ., 47, 159-174, https://doi.org/10.1016/0167-8809(93)90109-3, 1993.
Posch, M., Vries de, W., and Sverdrup, H.: Mass Balance models to derive critical loads of nitrogen and acidity for terrestrial and aquatic ecosystems, in: Critical Loads and Dynamic Risk Assessments, edited by: Vries de, W., Hettelingh, J.-P., and Posch, M., Environmental Pollution, 25, Springer, Dordrecht, Heidelberg, New York, London, 171-205, https://doi.org/10.1007/97894-017-9508-1_6, 2015.

Raspe, S., Bastrup-Birk, A., Fleck, S., Weis, W., Mayer, H., Meesenburg, H., Wagner, M., Schindler, D., and Gartner, K.: Meteorology, in: Forest Monitoring. Methods for terrestrial investigations in Europe with an overview of North America and Asia, edited by: Ferretti, M. and Fischer, R., Developments in Environmental Science, Vol. 12, Elsevier, 319-336, 2013.

Rautio, P., Fürst, A., Stefan, K., Raitio, H., and Bartels, U.: Part XII: Sampling and Analysis of Needles and Leaves, in: UNECE ICP Forests Programme Co-ordinating Centre: Manual on methods and criteria for harmonized sampling, assessment, monitoring and analysis of the effects of air pollution on forests. Thünen Institute of Forest Ecosystems, Eberswalde, Germany, 19 pp. + Annex, available at: http://icp-forests.net/page/ icp-forests-manual (last access: 19 June 2021), 2016.

R Development Core Team: R: A language and environment for statistical computing. R Foundation for Statistical Computing, Vienna, Austria, available at: http://www.R-project.org (last access: 5 February 2018), 2017.

Reil, D., Imholt, C., Eccard, J. A., and Jacob, J.: Beech Fructification and Bank Vole Population Dynamics Combined Analyses of Promoters of Human Puumala Virus Infections in Germany, PLOS ONE, 10, e0134124, https://doi.org/10.1371/journal.pone.0134124, 2015.

Rhodes, J. R., McAlpine, C. A., Zuur, A. F., Smith, G. M., and Ieno, E. N.: GLMM Applied on the Spatial Distribution of Koalas in a Fragmented Landscape, in: Mixed effects models and extensions in ecology with R, edited by: Zuur, A. F., Ieno, E. N., Walker, N. J., Sveliev, A. A., and Smith, G. M., Statistics for Biology and Health, Springer, 469-492, https://doi.org/10.1007/978-0387-87458-6_21, 2009.

Schäfer, M. and Schauermann, J.: Soil fauna, in: Functioning and Management of European Beech Ecosystems, edited by: Brumme, R. and Khanna, P., Ecol. Stud., Vol. 208, Springer, Berlin, Heidelberg, 93-104, https://doi.org/10.1007/b82392_8, 2009.

Schäfer, M., Migge-Kleian, S., and Scheu, S.: The role of soil fauna for decomposition of plant residues, in: Functioning and Management of European Beech Ecosystems, edited by: Brumme, R. and Khanna, P., Ecol. Stud., Vol. 208, Springer, Berlin, Heidelberg, 207-230, https://doi.org/10.1007/b82392_13, 2009.

Schmidt, W.: Zeitliche Veränderung der Fruktifikation bei der Rotbuche (Fagus sylvatica L.) in einem Kalkbuchenwald (19812004), Allg. Forst-u. J.-Ztg., 177, 9-19, 2006.

Schmidt-Walter, P., Ahrends, B., Mette, T., Puhlmann, H., and Meesenburg, H.: NFIWADS: The water budget, soil moisture, and drought stress indicators database for German National Forest Inventory (NFI), Ann. Forest Sci., 76, 39, https://doi.org/10.1007/s13595-019-0822-2, 2019.

Schulte-Bisping, H., Brumme, R., and Priesack, E.: Nitrous oxide emission inventory of German forest soils, J. Geophys. Res.Atmos., 108, 4132, https://doi.org/10.1029/2002jd002292, 2003. 
Smith, V. H.: Effects of resource supplies on the structure and function of microbial communities, Antonie van Leeuwenhoek, 81, 99-106, https://doi.org/10.1023/A:1020533727307, 2002.

Solberg, S., Dobbertin, M., Reinds, G. J., Lange, H., Andreassen, K., Fernandez, P. G., Hildingsson, A., and DeVries, W.: Analyses of the impact of changes in atmospheric deposition and climate on forest growth in European monitoring plots: A stand growth approach, Forest Ecol. Manag., 258, 1735-1750, https://doi.org/10.1016/j.foreco.2008.09.057, 2009.

Swift, M. J., Heal, O. W., and Anderson, J. M.: Decomposition in Terrestrial Ecosystems Studies, in: Ecology, Vol. 5, Blackwell Scientific Publications, Oxford, 1979.

Talkner, U., Meiwes, K. J., Potočić, N., Seletković, I., Cools, N., De Vos, B., and Rautio, P.: Phosphorus nutrition of beech (Fagus sylvatica L.) is decreasing in Europe, Ann. Forest Sci., 72, 919928, https://doi.org/10.1007/s13595-015-0459-8, 2015.

Thiele, J. C., Nuske, R., Ahrends, B., Panferov, O., Albert, M., Staupendahl, K., Junghans, U., Jansen, M., and Saborowski, J.: Climate change impact assessment - A simulation experiment with Norway spruce for a forest district in Central Europe, Ecol. Model., 346, 30-47, https://doi.org/10.1016/j.ecolmodel.2016.11.013, 2017.

Tietema, A., Emmett, B. A., Gundersen, P., Kjønaas, O. J., and Koopmans, C. J.: The fate of ${ }^{15} \mathrm{~N}$-labelled nitrogen deposition in coniferous forest ecosystems, Forest Ecol. Manag., 101, 19-27, https://doi.org/10.1016/S0378-1127(97)00123-0, 1998.

Ukonmaanaho, L., Pitman, R., Bastrup-Birk, A., Breda, N., and Rautio, P.: Part XIII: Sampling and Analysis of Litterfall. I, in: UNECE ICP Forests Programme Co-ordinating Centre: Manual on methods and criteria for harmonized sampling, assessment, monitoring and analysis of the effects of air pollution on forests, Thünen Institute for Forests Ecosystems, Eberswalde, Germany, 14 pp., available at: http://icp-forests.net/page/ icp-forests-manual (last access: 19 June 2021), 2016.
Ulrich, B.: Forest ecosystem theory based on material balance, Ecol. Model., 63, 163-183, https://doi.org/10.1016/03043800(92)90068-P, 1992.

Ulrich, B.: Nutrient and Acid-Base Budget of Central European Forest Ecosystems, in: Effects of Acid Rain on Forest Processes, edited by: Godbold, D. and Hüttermann, A., Wiley-Liss, New York, 1-50, 1994.

UNECE ICP Forests Programme Co-ordinating Centre (Ed.): Manual on methods and criteria for harmonized sampling, assessment, monitoring and analysis of the effects of air pollution on forests, Thünen Institute of Forest Ecosystems, Eberswalde, available at: http://icp-forests.net/page/icp-forests-manual (last access: 19 June 2021), 2016.

Vacchiano, G., Hacket-Pain, A., Turco, M., Motta, R., Maringer, J., Conedera, M., Drobyshev, I., and Ascoli, D.: Spatial patterns and broad-scale weather cues of beech mast seeding in Europe, New Phytol., 215, 595-608, https://doi.org/10.1111/nph.14600, 2017.

Wachter, H.: Über die Beziehungen zwischen Witterung und Buchenmastjahren, Forstarchiv, 36, 69-78, 1964.

Wutzler, T., Wirth, C., and Schumacher, J.: Generic biomass functions for Common beech (Fagus sylvatica) in Central Europe: predictions and components of uncertainty, Can. J. Forest Res., 38, 1661-1675, https://doi.org/10.1139/X07-194, 2008.

Zackrisson, O., Nilsson, M.-C., Jäderlund, A., and Wardle, D. A.: Nutritional Effects of Seed Fall during Mast Years in Boreal Forest, Oikos, 84, 17-26, https://doi.org/10.2307/3546862, 1999.

Zeller, B., Colin-Belgrand, M., Dambrine, E., and Martin, F.: Fate of nitrogen released from ${ }^{15} \mathrm{~N}$-labeled litter in European beech forests, Tree Physiol., 21, 153-162, https://doi.org/10.1093/treephys/21.2-3.153, 2001. 